Article

\title{
Treated Wastewater and Fertigation Applied for Greenhouse Tomato Cultivation Grown in Municipal Solid Waste Compost and Soil Mixtures
}

\author{
Nikolaos Tzortzakis ${ }^{1,2, * \mathbb{C}}$, Christos Saridakis ${ }^{1}$ and Antonios Chrysargyris ${ }^{2}$ \\ 1 Department of Organic Greenhouse Crops and Floriculture, School of Agricultural Technology, \\ Technological Educational Institute of Crete, 71410 Heraklion, Greece; christos.saridakis@yahoo.gr \\ 2 Department of Agricultural Sciences, Biotechnology and Food Science, Cyprus University of Technology, \\ 3036 Limassol, Cyprus; a.chrysargyris@cut.ac.cy \\ * Correspondence: nikolaos.tzortzakis@cut.ac.cy; Tel.: +357-25002280
}

Received: 8 May 2020; Accepted: 19 May 2020; Published: 24 May 2020

\begin{abstract}
Low-fertility soil and the use of brackish water for irrigation act as obstacles and limit crop production. The utilization of municipal solid waste (MSW), compost (C), and treated wastewater (TWW) is receiving attention nowadays not only to overcome the above limitations but also as an efficient way for waste management and reuse of raw materials. In the present study, MSW compost in different ratios $(5 \%, 10 \%, 20 \%$, and $40 \%)$, fertigation and/or irrigation with TWW were studied in tomato plants (Solanum lycopersicum L.). The addition of compost increased organic content, $\mathrm{pH}$, electrical conductivity (EC), and mineral content of the growing media, while fertigation and TWW supported the mineral status of the growing media, and this was reflected in the increase of $\mathrm{N}, \mathrm{K}$, and $\mathrm{Na}$ in tomato leaves. Plants grown in compost-based media with fertigation produced more leaves, compared to the control, while irrigation with TWW did not increase the number of leaves. Plant biomass increased with the application of $\geq 20 \% \mathrm{C}$, fertigation, and/or TWW applications. Plant yield increased in $40 \% \mathrm{C}$, while fertigation increased yield in case of lower (5\%-10\% C) compost ratios, but TWW application did not change the yield. The combination of high $\mathrm{C}$ ratios and fertigation and/or TWW decreased tomato fresh weight. Different levels of $\mathrm{C}$ did not affect leaf photosynthesis, stomatal conductance, internal $\mathrm{CO}_{2}$ concentration, and chlorophyll fluorescence, but, in general, the combination of compost with fertigation and/or TWW affected them negatively. Fruit total soluble solids, acidity, ascorbic acid, firmness, and total phenolics were increased with the high ratios of compost and/or fertigation and TWW applications, but marketability did not. Bacteria (total coliform and Escherichia coli) units increased in growing media subjected to TWW, but lower levels were counted on the fruit, mainly due to splashing or fruit contact with the soil. The results indicate that up to $40 \% \mathrm{C}$ can be added into the substrate, as increased plant growth and maintained plant yield for greenhouse tomato cultivation is observed, while fertigation and TWW could be used in a controlled manner as alternative means for nutrient and irrigation in vegetables following safety aspects.
\end{abstract}

Keywords: compost; municipal solid wastes; growth; quality; fertigation; tomato; wastewater

\section{Introduction}

Waste management in cities is a great challenge with increased environmental concern; there are severe problems caused by waste accumulation in the areas that are related to increased population, urbanization, and industrialization [1]. Over $487 \mathrm{~kg}$ of municipal waste per capita were generated yearly in the European Union in 2017 [2]. Inefficient municipal solid waste (MSW) management includes waste-filled land and contamination of underground water sources. This leads to environmental and 
health-related issues [3], and to the production of combustible gases $\left(\mathrm{CO}_{2}\right.$ and $\left.\mathrm{CH}_{4}\right)$ that amplify the greenhouse effect [4]. Typical feedstocks of MSW consist of building materials, consumer goods, packing materials, residential pruning green yard waste and food wastes, to name a few. The applications of MSW should always take into account their impact on the environment, human and other organism health. Strategies for mixing digested sludge with compost are currently applied to reduce the environmental risk posed by each material and to maximize its nutrient levels [5].

The application of composted MSW as an alternative approach to landfill incineration and disposal is promoted by environmental agencies because it contributes to the restoration of the soil's organic matter [6,7] and to a sustainable crop production [8]. Compost (C) is a suitable way of waste management and material recycling, by turning large volumes of MSW into materials that contribute to the soil organic matter and minerals, having an impact on the physicochemical and microbial properties of the soil [9-11], and by bioremediating contaminated soils [12]. However, the use of compost as growing media component can affect plant growth and yield, as it may cause problems of high salt levels and unsuitable media physicochemical characteristics [6]. Compost quality such as stability and maturity should be tested before compost is applied to soil, as immature compost can adversely affect plant growth and soil characteristics by decreasing oxygen and available nitrogen $(\mathrm{N})$ levels or releasing phytotoxic components [13]. Moreover, compost of MSW may have high levels of trace elements and heavy metals; Paradelo et al. [14] reported copper $(\mathrm{Cu})$, lead $(\mathrm{Pb})$, and zinc $(\mathrm{Zn})$ accumulation in plant tissue. Nutrient accumulation in plant is related to mineral availability in soil, soil properties, and changes in the $\mathrm{pH}$, but is also species specific [7]. MSW compost addition has an alkalinized effect on soils while repeated and long term MSW compost applications might have a destructive effect on crop production and nutrient status [15]. Additionally, Ozores-Hampton et al. [16] reported the accumulation of various heavy metals and trace elements in the soil after MSW compost application in tomato crops but not in tomato fruit. Ribeiro et al. [17] exhibited the increased growth of potted geranium when MSW compost was mixed with peat at $10 \%-20 \%$, while Castillo et al. [18] recommended the use of $30 \%$ MSW compost in peat instead of pure peat as growing media for tomato seedling production. Moreover, low MSW compost levels (10\%-30\%) were recommended for eggplant [19], watermelon [20], and pepper [21] seedling production in peat-based growing media. Interestingly, MSW compost was able to reduce (up to 60\%) cadmium (Cd) levels in onion, spinach, and lettuce, indicating the importance of the MSW compost as a low-cost soil conditioner, effective enough to reduce $\mathrm{Cd}$ accumulation in plants [22].

For most agricultural areas of the Mediterranean basin, the amount of organic matter is poor due to the arid and semi-arid climates. Bostani [23] emphasized the role of the organic matter of the MSW compost in affecting the availability of nutrients to the plants, as exampled for iron $(\mathrm{Fe})$ fractionation and availability. The low-fertility status of soils can be improved through the use of organic fertilization by using peat, manure, sewage sludge, or compost [24].

In arid and semi-arid areas, as in the largest part of the Mediterranean basin, water demand for agricultural use is increasing in parallel with the increased population, the demanding living standards, and climate change worldwide. However, water availability is decreased, and alternative water sources are desired [25]. It is possible to treat and reuse urban and industrial wastewater for various purposes, mostly for agricultural uses [26]. Wastewater is one of the main forms of poor quality water, as different technologies have been applied to improve its quality and meet health and environmental issues, with general public constraints [27]. Depending on the technology applied, treated wastewater (TWW) is mainly divided in primary, secondary, and tertiary-treated wastewater $[25,28]$. A large scientific portfolio on wastewater treatment, reuse, and applications in agriculture supports our knowledge, but ongoing research in this area is investigating a way to maximize the efficacy of wastewater in agriculture, with both qualitative and quantitative outcomes, without environmental and health-related risks [25,28-30]. Applications of wastewater in agriculture do affect the chemical properties of the upper level $(<0.3 \mathrm{~m})$ of the soil and plant chemical composition [31]. Several studies have reported 
the use of wastewater for vegetables and ornamentals [29,31-34], with applications in high-demand growing systems such as hydroponics [28].

The increased consumer needs and demands for vegetable production throughout the calendar year are a great challenge to the commodities' quality and safety. This requires additional nutrients in the soil that can be added either by increased fertilizer applications or alternative use of other sources, such as compost and treated wastewater, which affect the physicochemical and nutrient composition of the soil, in parallel with the efficient waste management. The present study examined the effects of (i) different ratios of municipal solid waste compost mixed with soil, (ii) fertigation used, and (iii) the quality of irrigation water (tap water and tertiary-treated wastewater), either alone or with fertilizers, in tomato plant growth, physiology, fruit quality, and safety-related attributes in greenhouse crops, replacing part of the fertilizers and/or irrigation water with alternative sources.

\section{Materials and Methods}

\subsection{Plant Material and Compost}

Municipal solid waste compost was obtained from the Inter-Municipal Enterprise for the Management of Solid Wastes at the prefecture of Chania, Greece. Organic fractions of municipal waste were used for the compost preparation. Organic material was composted for a period of 56 months and then sieved with the majority $(\sim 60 \%)$ of particles sized $<4 \mathrm{~mm}$. The chemical properties of the final material were previously presented [35], and are briefly mentioned here: $\mathrm{pH}$ of 7.51; electrical conductivity (EC) of $16.54 \mathrm{mS} \mathrm{cm}^{-1}$; organic $\mathrm{C}$ of $26.62 \%$; total $\mathrm{N}$ of $0.57 \%$; $\mathrm{P}$ of $164 \mathrm{mg} \mathrm{kg}^{-1}$; $\mathrm{K}: 727 \mathrm{mg} \mathrm{kg}^{-1}$; Mg: $386 \mathrm{mg} \mathrm{kg}^{-1}$; Ca: $645 \mathrm{mg} \mathrm{kg}^{-1}$; and Na: $403 \mathrm{mg} \mathrm{kg}^{-1}$.

Tomato (Solanum lycopersicum L. cv. 1414) seedlings were purchased from a commercial nursery and plants were grown during the autumn-winter period.

\subsection{Treated Wastewater}

Primary-treated wastewater was collected from the sewage treatment unit of Heraklion (180,000 p.e.), Crete, Greece. Tertiary-treated wastewater (tertiary-TWW) was collected by treating the effluent of packed bed filters (Advantex-AX20, Orenco; used for secondary-treated wastewater) using sand filtration and chlorination process (obtained by the lab of Solid Waste and Wastewater Management at the Technological Educational Institute of Crete, Greece), while the physicochemical properties of the tertiary-TWW used in the experiment were analyzed as documented previously [30]. In brief, the chemical characteristics of tertiary-TWW and tap water (in parenthesis) sources used in the present study were: $\mathrm{pH}$ of $7.5(7.8)$; $\mathrm{EC}\left(\mathrm{mS} \mathrm{cm}^{-1}\right)$ of $1.1(0.7)$; chemical oxygen demand, $\mathrm{COD}\left(\mathrm{mg} \mathrm{L}^{-1}\right)$ of 24 (16); total soluble solids, TSS ( $\mathrm{mg} \mathrm{L}^{-1}$ ) of 9.1 (2.6); total nitrogen, TN (mg L ${ }^{-1}$ ) of 20.0 (4.7); total phosphorus, TP (mg L ${ }^{-1}$ ) of 8.0 (2.0); boron, $\mathrm{B}\left(\mathrm{mg} \mathrm{L}^{-1}\right)$ of 251.2 (16.4); magnesium, $\mathrm{Mg}\left(\mathrm{mg} \mathrm{L}^{-1}\right)$ of 51.2 (19.1); calcium, Ca (mg L ${ }^{-1}$ ) of 123.0 (60.5); potassium, $\mathrm{K}\left(\mathrm{mg} \mathrm{L}^{-1}\right)$ of 28.5 (not detected); zinc, $\mathrm{Zn}\left(\mu \mathrm{g} \mathrm{L}^{-1}\right)$ of 7.0 (not detected).

\subsection{Experimental Set Up}

The experiment was implemented in an unheated plastic greenhouse in Crete, Greece. Tomato seedlings were grown in peat-based substrate. Two media, soil (S) and compost (C) derived from municipal solid waste, and mixtures of them, were used to make five substrates, which were: (1) $0 \%$ C (soil) as control; (2) 5\% C (S:C 95:5); (3) 10\% C (S:C 90:10); (4) 20\% C (S:C 80:20); and (5) 40\% C (S:C 60:40). Plants grown in the above substrates were irrigated with tap water (Treatments 1-5) or fertigated following from the above: (6) $0 \% \mathrm{C}+\mathrm{Fert}$; (7) $5 \% \mathrm{C}+\mathrm{Fert}$; (8) 10\% C+Fert; (9) $20 \%$ C+Fert; and (10) $40 \% \mathrm{C}+$ Fert (Treatments 6-10). Additionally, plants grown in the above substrates were irrigated with tertiary-treated wastewater without fertigation following from the above: (11) $0 \%$ C+TWW; (12) 5\% C+TWW; (13) 10\% C+TWW; (14) 20\% C+TWW; and (15) $40 \%$ C+TWW (Treatments 11-15) or with fertigation following from the above: (16) $0 \% \mathrm{C}+\mathrm{TWW}+\mathrm{Fert}$; (17) $5 \%$ 
C+TWW+Fert; (18) 10\% C+TWW+Fert; (19) $20 \%$ C+TWW+Fert; and (20) 40\% C+TWW+Fert (Treatments 16-20). A total of 20 treatments (combinations of compost ratio, fertigation and/or TWW) were used with 3 replications/treatment and 4 plants/replication. Therefore, each treatment was applied to 12 tomato plants.

Tomato seedlings were transplanted in single pots ( $9 \mathrm{~L}$ capacity pots filled with substrate) and arranged with a completed randomized pattern in single rows. The rows were $1.0 \mathrm{~m}$ apart and $0.45 \mathrm{~m}$ divided the plants. Drip irrigation emitters ( 1 emitter/pot) were installed and irrigation occurred two times (1.5 $\mathrm{min} /$ time) per day, or according to crop needs, using a timer and pressure pumps. Fertigation (EC: $2.5 \mathrm{mS} \mathrm{cm}^{-1} ; 200 \mathrm{~mL}$ plant $^{-1}$ ) with commercial (i.e., 20-20-20; 11-15-15) fertilizers was applied (manually) once a week. The drainage solution from each plant was collected in each pot tray, and was available via capillary suction for plant water needs. Plants were handled on a string according to the single pruning scheme (the main stem grew vertically).

\subsection{Measurements}

The soil used in the present study was characterized as a fertile one, as this was indicated from the physicochemical properties measured, as previously described [36]. Organic matter content was determined by loss-on-ignition method. The equivalent calcium carbonate was determined using the calcimeter method. The EC and $\mathrm{pH}$ were determined according to 1:1 soil to solution ratio, employing a portable pH/EC-meter (HI 98130 HR, Hanna Instruments, USA). Nutrient analyses for K and Na (photometric; JENWAY, PEP-7 Jenway, Dunmow, UK), and P (spectrophotometric; Pye Unicam Hitachi U-1100, Tokyo, Japan) were determined while total $\mathrm{N}$ was determined by means of Kjeldahl. The soil was mixed with sand at a ratio of 2:1. Soil mixture had: $0.82 \%$ organic matter $(0.48 \%$ organic carbon); $\mathrm{C} / \mathrm{N}$ 8; pH 6.9; EC $0.71 \mathrm{mS} \mathrm{cm}^{-1}$; total $\mathrm{N} 140 \mathrm{mg} \mathrm{kg}^{-1}$; P $21.7 \mathrm{mg} \mathrm{kg}^{-1}$; $\mathrm{K} 5.5 \mathrm{mg} \mathrm{kg}^{-1}$; and Na $0.32 \mathrm{mg} \mathrm{kg}^{-1}$.

Two weeks after transplanting, the effects of compost, fertigation, and irrigation water quality on plant growth and yield in tomato were studied. Height of plant, diameter of main stem, number of leaves, number of flowers and fruits, as well as chlorophyll fluorescence (Chlorophyll fluorometer; Opti-Sciences OS-30p, UK) were measured. Leaf photosynthetic rate ( $p n)$, stomatal conductance ( $g s$ ), and internal leaf concentration of $\mathrm{CO}_{2}(\mathrm{Ci})$ were measured with a portable infrared gas analyzer (model Li-6200, Li-Cor, Inc., Lincoln, NE, USA). Measurements were taken between 9:00 and 11:15 AM with conditions of leaf temperature within the chamber $28 \pm 2{ }^{\circ} \mathrm{C}$, and photosynthetic photon flux density of $1300 \mu \mathrm{mol} \mathrm{m} \mathrm{m}^{-2} \mathrm{~s}^{-1}$ at the ambient $\mathrm{CO}_{2}$ concentration and leaf chamber area of $6.0 \mathrm{~cm}^{2}$, as previously described [19]. Two measurements took place for each of the nine plants (replicates) per treatment. Plant yield was assessed throughout the experiment as a cumulative result of individual fruit harvesting and fresh weight. Plant biomass (fresh weight in grams and dry matter content in percentage) was determined at the end of the experiment. Leaf nutrient accumulation tested in four replicates/treatment (each replicate was a pool of two leaves). Samples were ashed, acid digested $(1 \mathrm{~N} \mathrm{HCl})$, and nutrient analysis for $\mathrm{K}$ and $\mathrm{Na}$ (photometric; JENWAY, PEP-7 Jenway, Dunmow, UK), and P (spectrophotometric; Pye Unicam Hitachi U-1100, Tokyo, Japan) were determined while total N was determined by means of Kjeldahl. Data were expressed in mg per kg of dry weight.

Harvested fruits were examined for fruit quality-related parameters. Fruit fresh weight (in g), and fruit size (length and diameter in $\mathrm{cm}$ ) were measured in each harvested fruit. Fruit color was measured using the Hunter Lab System and a Minolta colorimeter model CR300 (Konica Minolta, Osaka, Japan). Values were recorded from 2 points around the equator of each fruit for $L^{*}, a^{*}$, and $b^{*}$ while parameters as chroma value $(C)$, hue $(h)$, and color index $(C I)$ were calculated as described previously [37]. Fruit marketability was assessed by using a 1-4 scale (1: extra quality; 2: good quality; 3: medium quality (i.e., small size, decolorization); 4: not marketable quality (i.e., malformation, wounds, infection)) and results were expressed in percentage. Symptoms of cracking, malformation and blossom end rot (BER) were also recorded. 
Fruit firmness was assessed at two points on each tomato's shoulder using a texture-meter FT 011 (TR Scientific Instruments, Forli, Italy) with an 8-mm plunger. The amount of force (in Newtons; N) needed to break through the tomato's radial pericarp (i.e., surface) in eight replicates was measured at room temperature. Total soluble solids (TSS in ${ }^{\circ}$ Brix) of the fruit juice was measured by a digital refractometer (model Atago PR-101, Atago Co. Ltd., Tokyo, Japan). Titratable acidity (TA) was assayed via potentiometric titration (Mettler Toledo DL22, Columbus, OH, USA) of $5 \mathrm{~mL}$ supernatant diluted to $50 \mathrm{~mL}$ with distilled water using $0.1 \mathrm{~N} \mathrm{NaOH}$ up to $\mathrm{pH}$ 8.1. Results were expressed in citric acid percentage. The fruit sweetness/ripening index was calculated using TSS/TA ratio. The $\mathrm{pH}$ and EC of the fruit juice were also measured. Twelve measurements for each treatment took place.

Ascorbic acid (AA; which consists of the main part of vitamin C) was measured using the 2,6-dichloroindophenol titrimetric method as previously described [37]. An aliquot of $5 \mathrm{~mL}$ of pooled tomato juice was diluted with $5 \mathrm{~mL}$ of water and titrated by the dye solution until the color changed. Data were expressed as mg of AA per gram of fresh weight. Total phenolic content was measured on blended fruit tissue ( $5 \mathrm{~g}$ ) extracts following repeated (4-fold) addition of $2.5 \mathrm{~mL}$ of $50 \%(\mathrm{v} / \mathrm{v})$ methanol, as reported previously [38]. Results were expressed as gallic acid equivalents (GAE) per gram of fresh weight.

The microbial load of bacteria (total coliform and Escherichia coli) was assessed on the fruit surface ( $n=23$ ) and inside the fruit, using ChromoCult ${ }^{\circledR}$ Coliform Agar (Merck KGaA, Darmstadt, Germany), a selective and differential chromogenic culture medium [39]. Harvested fruits were placed in sterile plastic bags (one fruit per bag), which were then filled with $225 \mathrm{~mL}$ of sterile Butterfield phosphate buffered water (42.5 $\mathrm{g} \mathrm{L}^{-1} \mathrm{KH}_{2} \mathrm{PO}_{4}, \mathrm{pH} 7.2$, Merck, Kenilworth, NJ, USA) and shaken gently to rinse off most of the bacteria present. Under sterile conditions, $1 \mathrm{~mL}$ of the solution was applied to a $0.45-\mu \mathrm{m}$ membrane in vacuum for isolation of coliform cultures. Inoculated membrane was transferred to a Petri dish containing ChromoCult ${ }^{\circledR}$ Coliform Agar, and incubated at $35{ }^{\circ} \mathrm{C}$ for $24-48$ h. Pink colonies resulting from salmon-galactoside cleavage by $\beta$-d-galactosidase were classified as total coliform counts, while dark blue colonies resulting from salmon-galactoside and X-glucuronide cleavage by $\beta$-d-galactosidase and $\beta$-d-glucuronidase were classified as presumptive E. coli colonies [40]. Fruits were then disinfected by multiple washings with chlorine solution, cut in four pieces, and placed in sterile plastic bags (one fruit cut per bag) with the Butterfield phosphate buffered water, gently shaken to rinse the possible bacteria present inside the fruit. Similarly, soil samples $(n=5)$ were tested for bacteria units' presence (total coliform and Escherichia coli).

\subsection{Statistical Analysis}

Data were tested for normality and then subjected to analysis of variance (ANOVA). Significant differences between mean values were separated by using Duncan's Multiple Range Test $(p=0.05)$ following one-way ANOVA. Correlation coefficients were also tested for the effects of the three factors (compost, fertilizer, treated wastewater) on the tomato crop; statistical analysis was performed with the aid of SPSS (SPSS Inc., Chicago, IL, USA). Pairwise metabolite effect correlations were calculated by Pearson's correlation test using the R program.

\section{Results and Discussion}

Linear correlation coefficients were determined and are presented in detail in Table S1. The correlation coefficient $(r)$ and $p$-values between the analyzed factors (compost, fertilizer, and TWW) and tomato growth, physiology, and fruit quality-related parameters are given. Compost application in different ratios was positively correlated with stem diameter, plant biomass, leaf content for $\mathrm{K}, \mathrm{Na}$ and $\mathrm{N}$, fruit number, fruit marketability, color $a^{*}$ and CI, fruit EC, TSS and TA, but negatively correlated with physiology parameters (photosynthesis, stomatal conductance, internal $\mathrm{CO}_{2}$ concentration, and chlorophyll fluorescence), fruit fresh weight and size. Fertilizer application was positively correlated with plant height, number of leaves, flowers and fruits produced, plant biomass, yield, and photosynthesis, but negatively correlated with plant dry matter content. The application of TWW 
was positively correlated with the number of leaves and flowers, plant biomass, leaf content of $\mathrm{P}$ and $\mathrm{Na}$, fruit $\mathrm{CI}$, fruit EC, TSS, ripening, ascorbic acid, and content of phenols, but negatively correlated with plant dry matter content, internal $\mathrm{CO}_{2}$ concentration, and fruit color $L^{*}$.

\subsection{Substrate Properties}

Municipal solid waste is a valuable raw material for the horticultural industry; being $60 \%-90 \%$ biodegradable, it can be used as a bulking material to absorb excess water [41]. The addition of municipal solid waste compost as an organic component into the soil increased the levels of organic matter, the $\mathrm{pH}$ and the EC of the substrate (Table 1), and these results are consistent with reported findings [17,42]. A higher amount of MSW compost in the soil resulted in increased content of N, $\mathrm{P}$, and $\mathrm{K}$, which altered the nutrient status of the medium, while the increased Na content might cause saline effects during plant growth. Similar observations with increased P levels by adding MSW compost were reported by Zhang et al. [43]. The presence of organic matter in the soil plays an important role in the nutrient storage and circulation that will be used for plant production [44]. The increased $\mathrm{C} / \mathrm{N}$ ratio followed by the increased ratio of compost in the soil can possibly decrease the available $\mathrm{N}$ in plants, as $\mathrm{N}$ will be used partially for the decomposition of organic matter by microorganisms. Weber et al. [45] stated that the slow and continuous release of $\mathrm{N}$ from the compost into the soil increases not only the soil fertility but also the mineralization conditions of organic matter, reducing $\mathrm{N}$ leaching and the risk of groundwater contamination by nitrate [46]. Waste application caused an increase of soil EC, a result that was also stated in previous studies (as reviewed by Asgharipour and Armin [47]), as EC is well linked to organic matter content in soil [48]. Growing media containing MSW compost up to $20 \%$ had acceptable EC values, as low soluble salt levels $\left(E C<3.5 \mathrm{mS} \mathrm{cm}^{-1}\right.$ ) are preferred for potting compost [49]. Increased nutrient levels in soil after immerging compost reduce the activity of soil microorganisms [50] and promote the micronutrient absorption by the plants [1]. The beneficial effects of composts on soil characteristics, however, depend on soil texture, moisture content, levels of organic matter and minerals [7], but this should always be assessed together with the potential detrimental effects from the various contaminates introduced to the soil, such as heavy metals [14,45].

Table 1. Physicochemical properties of growing media consisting of soil and municipal solid waste compost $(\mathrm{C})$ resulting in five substrates.

\begin{tabular}{|c|c|c|c|c|c|c|c|c|c|}
\hline & $\begin{array}{c}\text { Organic } \\
\text { Matter (\%) }\end{array}$ & $\begin{array}{c}\text { Organic } \\
\text { C (\%) }\end{array}$ & $\mathrm{pH}$ & $\begin{array}{c}\mathrm{EC} \\
\left(\mathrm{mS} \mathrm{cm}^{-1}\right)\end{array}$ & $\begin{array}{c}\text { Total N } \\
(\%)\end{array}$ & $\mathrm{C} / \mathrm{N}$ & $\begin{array}{c}P \\
\left(\mathrm{mg} \mathrm{kg}^{-1}\right)\end{array}$ & $\begin{array}{c}\mathrm{K} \\
\left(\mathrm{mg} \mathrm{kg}^{-1}\right)\end{array}$ & $\begin{array}{c}\mathrm{Na} \\
\left(\mathrm{mg} \mathrm{kg}^{-1}\right)\end{array}$ \\
\hline $0 \% \mathrm{C}$ & 0.825 & 0.48 & 6.94 & 0.71 & 0.014 & 21.7 & 21.73 & 5.55 & 0.32 \\
\hline $5 \% \mathrm{C}$ & 1.513 & 0.88 & 7.17 & 1.38 & 0.024 & 31.9 & 31.97 & 11.38 & 10.24 \\
\hline $10 \% \mathrm{C}$ & 2.098 & 1.22 & 7.33 & 2.03 & 0.056 & 53.8 & 53.79 & 25.93 & 26.11 \\
\hline $20 \% \mathrm{C}$ & 2.304 & 1.34 & 7.51 & 3.39 & 0.081 & 58.4 & 58.45 & 43.40 & 40.99 \\
\hline $40 \% \mathrm{C}$ & 4.506 & 2.61 & 7.58 & 7.35 & 0.168 & 79.8 & 79.88 & 124.37 & 117.02 \\
\hline
\end{tabular}

\subsection{Effect on Plant Growth and Yield}

Plants grown in mixtures with compost did not differ in height, but both fertigation and TWW increased the plant height (Table 2). In previous studies on pepper (Capsicum annuum L.), plants grown in $\geq 10 \% \mathrm{C}$ were taller when compared with plants grown in soil, following $105 \mathrm{~d}$ of growth [11]. Irrigation with TWW also increased the plant height, compared with plants irrigated with tap water, being in agreement with previous studies on tomato (S. lycopersicum Mill.), cucumber (Cucumis sativus L.), and pepper (C. annuum L.) [29,39]. Plants grown in compost-based media had a higher number of leaves (up to 37.6\%), compared to the control (soil); however, when fertigation took place, this effect did not persist when TWW was used. Plants grown in compost $(40 \% \mathrm{C})$ had thicker stems, compared to control and $5 \% \mathrm{C}$ treatments, as it was also evidenced in the pepper crop grown in the same type of compost [11]. Fertigation in $\geq 10 \% \mathrm{C}$ media $(\geq 10 \% \mathrm{C}+\mathrm{Fert})$ increased the number of flowers produced 
and resulted in thicker stems, probably due to the better nutrient balance with the compost application of higher rates and/or fertigation. However, such effects were not evident when TWW was used instead of tap water for irrigation. The increased levels of compost (i.e., $20 \%-40 \%$ C) in the growing media, the fertigation, and/or the TWW use increased the upper biomass production, compared to the soil and/or lower compost levels in the media, being in accordance with the increased biomass on MSW-compost-treated tea plants (Camellia sinensis L) [51] and pepper [39]. Furthermore, MSW compost at 40 ton ha $\mathrm{ha}^{-1}$ as soil amendment increased Mesembryanthemum edule biomass production as well as polyphenols and antioxidant capacity levels [52]. In some cases the fertigation in the high compost rates media decreased the dry matter content of the upper plant biomass, and this was also observed in pepper by Dagianta et al. [39]. Ribeiro et al. [17] reported decreased plant growth with $>20 \% \mathrm{C}$ because of a high level of salts in potted geraniums (Pelargonium $x$ hortorum Bailey). Dagianta et al. [39] reported increased plant biomass in TWW and/or fertigated pepper grown in soil.

Table 2. Effects of municipal solid waste compost (C; $0 \%-5 \%-10 \%-20 \%-40 \%)$ in soil irrigated with water (W) or treated wastewater (TWW) and with fertilizers (+Fert/-Fert) on plant height $(\mathrm{cm})$, leaf number, flower number, stem diameter (mm), upper biomass fresh fruit $\left(\mathrm{g} \mathrm{plant}^{-1}\right)$, and upper biomass dry matter $(\%)$ in a greenhouse tomato crop.

\begin{tabular}{|c|c|c|c|c|c|c|c|}
\hline & Compost & Height (cm) & Leaf No & Flower No & $\begin{array}{l}\text { Stem Diameter } \\
(\mathrm{mm})\end{array}$ & $\begin{array}{c}\text { Biomass } \\
\left.\text { g plant }^{-1}\right)\end{array}$ & $\begin{array}{l}\text { Biomass Dry } \\
\text { Content }(\%)\end{array}$ \\
\hline \multirow{5}{*}{ Water/-Fert (W) } & $0 \% \mathrm{C}$ & $115.83 \pm 9.37 a$ & $12.3 \pm 0.9 a$ & $5.1 \pm 0.7 \mathrm{~b}$ & $8.01 \pm 0.43 b$ & $315.51 \pm 13.23 b$ & $35.67 \pm 1.97 a$ \\
\hline & $5 \% \mathrm{C}$ & $96.91 \pm 6.10 \mathrm{a}$ & $13.3 \pm 1.2 \mathrm{a}$ & $4.8 \pm 0.7 \mathrm{~b}$ & $8.57 \pm 0.46 b$ & $320.80 \pm 8.62 \mathrm{ab}$ & $37.50 \pm 3.12 \mathrm{a}$ \\
\hline & $10 \% \mathrm{C}$ & $106.50 \pm 9.99 a$ & $13.1 \pm 1.4 \mathrm{a}$ & $7.1 \pm 0.9 \mathrm{ab}$ & $9.26 \pm 0.24 \mathrm{ab}$ & $345.67 \pm 18.09 \mathrm{ab}$ & $36.33 \pm 8.41 a$ \\
\hline & $20 \% \mathrm{C}$ & $109.41 \pm 9.09 a$ & $13.0 \pm 1.5 \mathrm{a}$ & $5.6 \pm 1.3 b$ & $8.75 \pm 0.59 \mathrm{ab}$ & $360.05 \pm 21.99 a$ & $34.61 \pm 5.18 a$ \\
\hline & $40 \% \mathrm{C}$ & $108.66 \pm 8.98 \mathrm{a}$ & $13.3 \pm 1.0 \mathrm{a}$ & $8.6 \pm 0.8 \mathrm{a}$ & $9.93 \pm 0.31 a$ & $376.08 \pm 17.48 \mathrm{a}$ & $35.55 \pm 5.51 \mathrm{a}$ \\
\hline \multirow{5}{*}{$\begin{array}{l}\text { Water/+Fert } \\
\quad(\mathrm{W}+\mathrm{F})\end{array}$} & $0 \% \mathrm{C}$ & $120.08 \pm 13.99 a$ & $13.3 \pm 1.7 \mathrm{~b}$ & $8.3 \pm 0.8 \mathrm{ab}$ & $8.08 \pm 0.57 b$ & $331.55 \pm 20.03 c$ & $39.65 \pm 4.88 \mathrm{a}$ \\
\hline & $5 \% \mathrm{C}$ & $137.66 \pm 8.19 a$ & $16.8 \pm 1.1 \mathrm{a}$ & $7.8 \pm 0.9 b$ & $9.29 \pm 0.40 \mathrm{ab}$ & $398.70 \pm 6.22 b$ & $28.81 \pm 2.15 b$ \\
\hline & $10 \% \mathrm{C}$ & $136.33 \pm 9.99 a$ & $18.3 \pm 0.9 a$ & $11.1 \pm 1.0 \mathrm{a}$ & $9.62 \pm 0.57 a$ & $401.65 \pm 16.36 b$ & $30.46 \pm 2.93 b$ \\
\hline & $20 \% \mathrm{C}$ & $125.5 \pm 4.19 a$ & $16.0 \pm 0.8 \mathrm{a}$ & $10.9 \pm 1.1 \mathrm{a}$ & $9.72 \pm 0.44 a$ & $442.51 \pm 19.74 b$ & $25.38 \pm 1.24 b$ \\
\hline & $40 \% \mathrm{C}$ & $125.75 \pm 3.49 \mathrm{a}$ & $17.0 \pm 0.5 \mathrm{a}$ & $10.8 \pm 1.0 \mathrm{a}$ & $9.71 \pm 0.32 \mathrm{a}$ & $514.73 \pm 20.21 a$ & $21.58 \pm 1.48 b$ \\
\hline \multirow{5}{*}{$\begin{array}{c}\text { Treated } \\
\text { wastewater/-Fert } \\
(\mathrm{TWW})\end{array}$} & $0 \% \mathrm{C}$ & $120.66 \pm 11.66 a$ & $15.8 \pm 1.8 \mathrm{a}$ & $9.8 \pm 1.6 a$ & $8.75 \pm 0.25 a$ & $400.21 \pm 17.38 b$ & $23.87 \pm 0.65 a$ \\
\hline & $5 \% \mathrm{C}$ & $114.50 \pm 6.22 \mathrm{a}$ & $15.5 \pm 1.0 \mathrm{a}$ & $8.5 \pm 0.8 \mathrm{a}$ & $8.51 \pm 0.44 a$ & $382.67 \pm 23.20 b$ & $26.18 \pm 1.59 a$ \\
\hline & $10 \% \mathrm{C}$ & $125.33 \pm 4.22 \mathrm{a}$ & $18.3 \pm 0.6 \mathrm{a}$ & $8.0 \pm 0.7 a$ & $9.58 \pm 0.58 \mathrm{a}$ & $449.53 \pm 15.73 a b$ & $21.34 \pm 0.86 a$ \\
\hline & $20 \% \mathrm{C}$ & $107.33 \pm 4.51 \mathrm{a}$ & $18.1 \pm 1.6 a$ & $8.3 \pm 0.8 a$ & $8.54 \pm 0.23 a$ & $429.46 \pm 12.13 \mathrm{ab}$ & $21.80 \pm 0.85 a$ \\
\hline & $40 \% \mathrm{C}$ & $120.66 \pm 7.37 a$ & $16.8 \pm 1.3 \mathrm{a}$ & $7.6 \pm 1.3 \mathrm{a}$ & $9.87 \pm 0.79 a$ & $501.86 \pm 39.79 a$ & $21.49 \pm 1.46 a$ \\
\hline \multirow{5}{*}{$\begin{array}{c}\text { Treated } \\
\text { wastewater/+Fert } \\
(\mathrm{TWW}+\mathrm{F})\end{array}$} & $0 \% \mathrm{C}$ & $137.00 \pm 6.97 \mathrm{a}$ & $18.5 \pm 0.7 \mathrm{a}$ & $11.1 \pm 0.9 \mathrm{a}$ & $9.25 \pm 0.67 a$ & $451.55 \pm 18.43 b$ & $22.14 \pm 1.29 \mathrm{ab}$ \\
\hline & $5 \% \mathrm{C}$ & $138.83 \pm 11.82 \mathrm{a}$ & $19.3 \pm 1.9 a$ & $12.3 \pm 2.5 a$ & $9.37 \pm 0.63 a$ & $507.48 \pm 48.99 \mathrm{ab}$ & $22.74 \pm 1.14 \mathrm{a}$ \\
\hline & $10 \% \mathrm{C}$ & $131.00 \pm 6.47 \mathrm{a}$ & $20.6 \pm 1.6 a$ & $11.1 \pm 1.7 \mathrm{a}$ & $9.02 \pm 0.61 \mathrm{a}$ & $474.61 \pm 16.81 \mathrm{ab}$ & $21.70 \pm 1.11 \mathrm{ab}$ \\
\hline & $20 \% \mathrm{C}$ & $132.83 \pm 6.26 a$ & $21.1 \pm 1.6 \mathrm{a}$ & $12.5 \pm 1.2 \mathrm{a}$ & $9.40 \pm 0.36 a$ & $545.28 \pm 56.91 \mathrm{ab}$ & $19.35 \pm 1.72 b$ \\
\hline & $40 \% \mathrm{C}$ & $129.83 \pm 4.05 a$ & $21.1 \pm 1.8 \mathrm{a}$ & $10.1 \pm 0.9 \mathrm{a}$ & $10.07 \pm 0.33 a$ & $571.45 \pm 15.90 \mathrm{a}$ & $19.31 \pm 1.09 b$ \\
\hline
\end{tabular}

Values $(n=6)$ in columns followed by the same letter for each water/fertilizer applications are not significantly different. $p \leq 0.05$.

Plant yield was significantly $(p<0.05)$ increased in $40 \%$ C, compared to the plants grown in soil (control) and this was attributed to the increased number of fruits produced rather than the fruit's fresh weight (Figure 1). Shanmugam and Warman [53] also reported increased yield in strawberries grown in sandy-loam soil and subjected to 37.5 ton ha $^{-1}$ of MSW compost. Similarly, Fagnano et al. [54] reported increased lettuce yield in plants grown in 10,30, and 60 ton ha ${ }^{-1}$, compared to control treatment. This could possibly be due to the lower $\mathrm{N}$ concentration in soils for the control plants, as the levels used in that study were similar to ours $\left(16,32\right.$, and 64 ton $^{\mathrm{ha}^{-1}}$ for the $10 \% \mathrm{C}, 20 \% \mathrm{C}$ and $40 \% \mathrm{C}$ treatments, respectively). This contrasts with previous studies on pepper, as plant yield decreased in $40 \% \mathrm{MSW}$ compost [39]. When fertigation was applied with tap water, plant yield was higher in plants grown in 5\%-10\% C-based media, compared to the control and to the higher rates of compost (i.e., $\geq 20 \%$ ), with increased fruit number in $10 \% \mathrm{C}+$ Fert and increased fruit fresh weight in $\leq 10 \% \mathrm{C}+$ Fert treatments. Warman et al. [55] reported decreased yield in squash over a 3-year study when MSW compost was applied in different ratios, compared with the fertilized (NPK) soil or a mixture of fertilized soil+MSW compost. This agrees with the present findings, as tomato yield decreased with the combination of high rates of compost and fertilizers. Nevertheless, some studies showed that inorganic fertilizers are 
superior to the MSW composts in supplying available N, while others showed increased yields in some crops following MSW compost application, and this depends on species/cultivar and salt resistance levels of the examined crops [7]. In such a way, MSW compost rates must be regulated based on the electrical conductivity of the applied compost and the species salt tolerance to avoid salt stress effects and unfavorable impacts on plant growth.

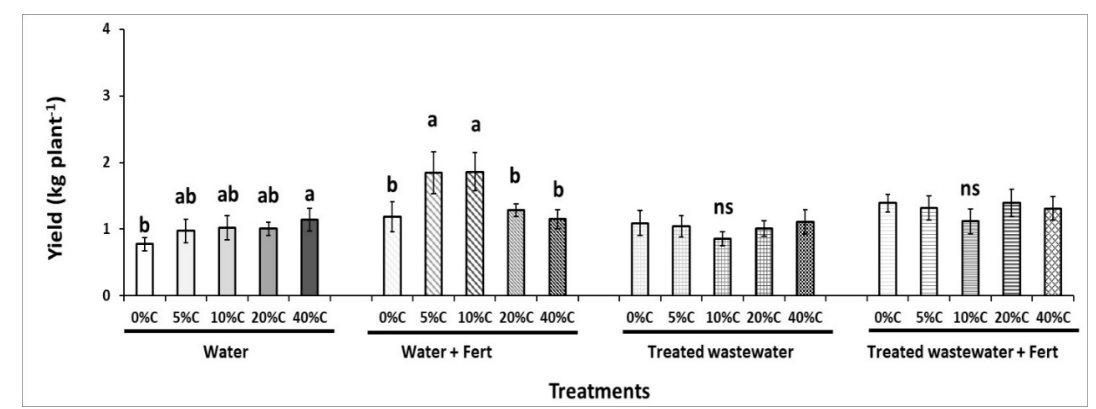

(a)

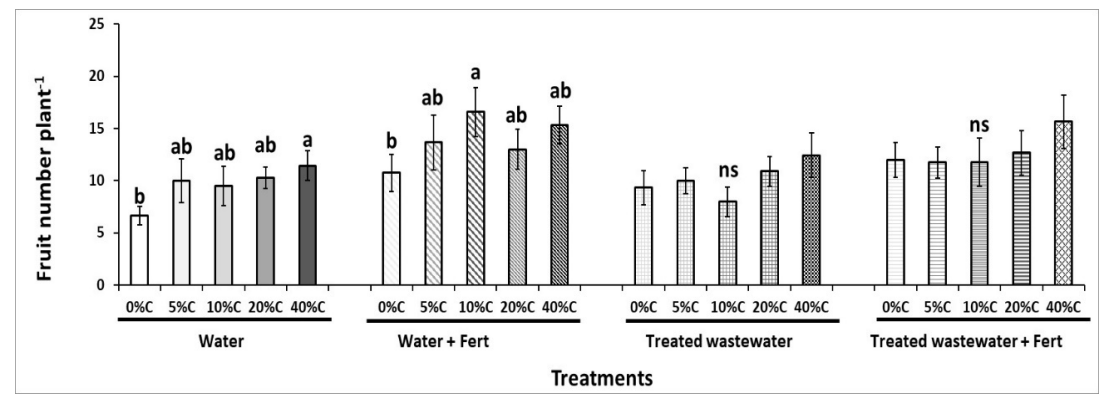

(b)

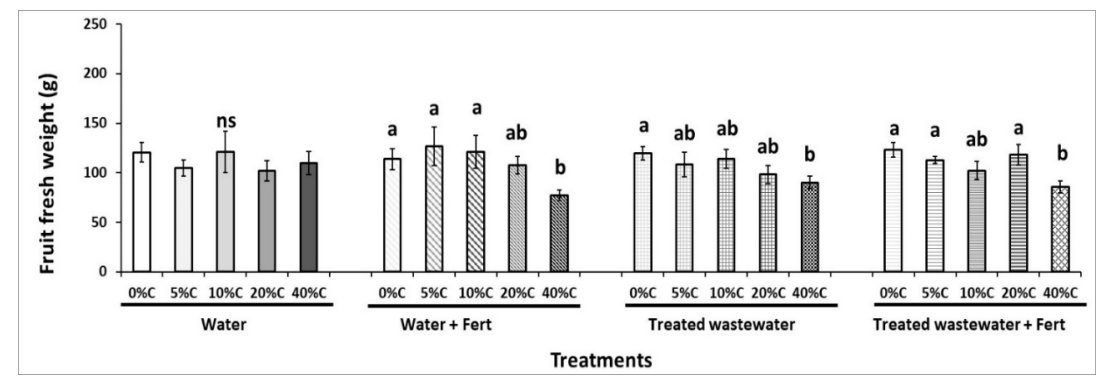

(c)

Figure 1. Effects of municipal solid waste compost (C; $0 \%-5 \%-10 \%-20 \%-40 \%)$ in soil irrigated with water $(\mathrm{W})$ or treated wastewater (TWW) and with fertilizers (+Fert/-Fert) on (a) yield $\left(\mathrm{g} \mathrm{plant}^{-1}\right)$, (b) fruit number per plant, and (c) fruit fresh weight $(\mathrm{g})$ in a greenhouse tomato crop. Data are means \pm SE $(n=9$ plants $)$ and significant differences $(p<0.05)$ among treatments are indicated by different letters. ns: not significant.

The application of wastewater in agriculture is an efficient strategy to meet the high demand for water for irrigation, and the exploitation of brackish water is attracting research interest despite the consumer concern [28]. Several researches on vegetables investigated the effects of wastewater on agriculture, including radish (Rapanus sativum L.) [30], tomato (S. lycopersicum Mill.) [29,33,56,57], cucumber (C. sativus L.) [28,29], eggplant (Solanum melogena L.) [32,57], cauliflower (Brassica oleracea var. botrytis), red cabbage (Brassica oleracea var. capitata) [31], and ornamentals [34,36]. In the present study, plants irrigated with TWW and/or fertigation (TWW+Fert) did not differ in yield and/or number of fruits produced, but fruit weight decreased with high compost rates (i.e., $40 \%$ C), compared with lower compost rates and relevant control. Similarly, Kiziloglu et al. [31] found no changes in cauliflower and red cabbage yields after wastewater application. The use of TWW was reported to increase the 
available $\mathrm{N}$ in the root zone of tomato and eggplant, and that was observed to increase the yield [32,57]. In lettuce, wastewater irrigation changed the soil's physicochemical properties and microbial load [58].

\subsection{Effect on Plant Physiology}

Compost ratios did not affect the tomato plant physiology as leaf photosynthesis (averaged as $7.68 \mu \mathrm{mol} \mathrm{m} \mathrm{m}^{-2} \mathrm{~s}^{-1}$ ), leaf stomatal conductance (averaged as $0.23 \mu \mathrm{mol} \mathrm{m}{ }^{-2} \mathrm{~s}^{-1}$ ), internal $\mathrm{CO}_{2}$ concentration (averaged as $309.63 \mu \mathrm{mol} \mathrm{mol}^{-1}$ ), and chlorophyll fluorescence (averaged as $0.72 \mathrm{Fv} / \mathrm{Fm}$ ) remained at similar levels among the examined compost ratios ( $0 \%-5 \%-10 \%-20 \%-40 \% \mathrm{C}$ ) used (Figure 2). This indicates the similar behavior of the crops during cultivation, with no changes in physiological aspects in terms of photosynthetic metabolism. Similar findings were observed in Cichorium spinosum grown in pots with MSW compost of $60 \mathrm{tha}^{-1}$, as total chlorophylls were unaffected [59]. Fertigation with tap water in $\geq 10 \% \mathrm{C}$ decreased leaf stomatal conductance, while internal $\mathrm{CO}_{2}$ concentration decreased in $\geq 20 \% \mathrm{C}+$ Fert. The use of TWW in $40 \% \mathrm{C}$ decreased (up to $43.1 \%$ and $31.2 \%$ ) photosynthesis and internal $\mathrm{CO}_{2}$ concentration, respectively. The combination of TWW and fertigation also decreased plant physiology attributes with more profound effects in $40 \% \mathrm{C}$ treatments.

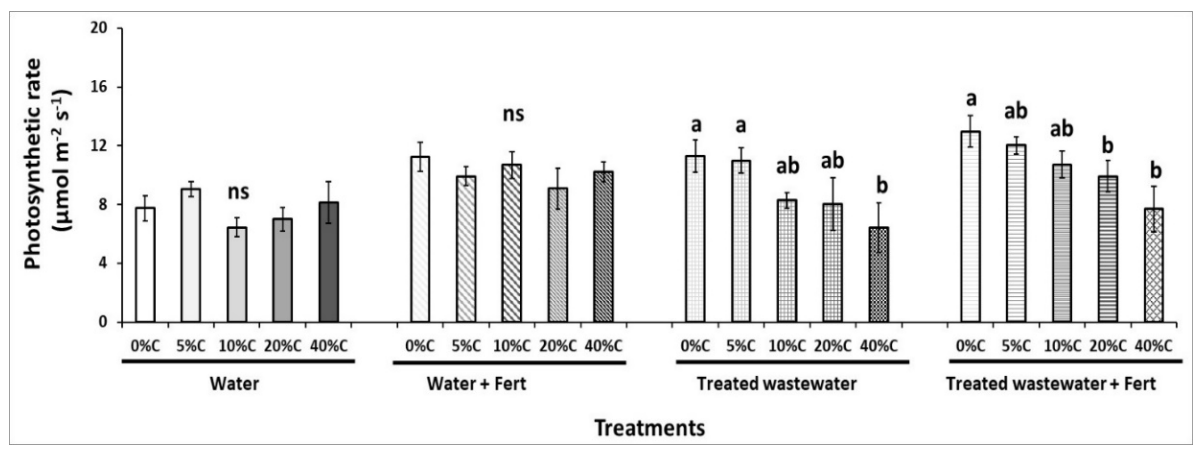

(a)

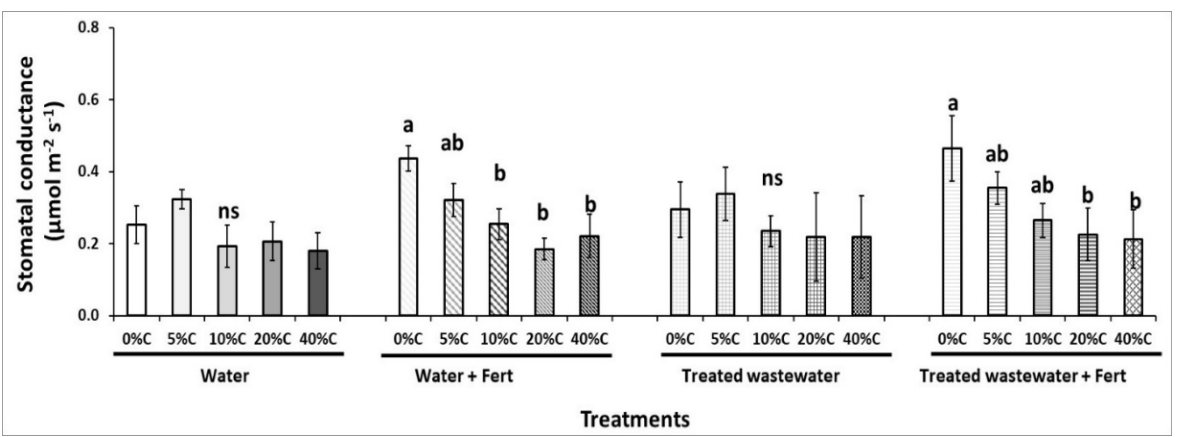

(b)

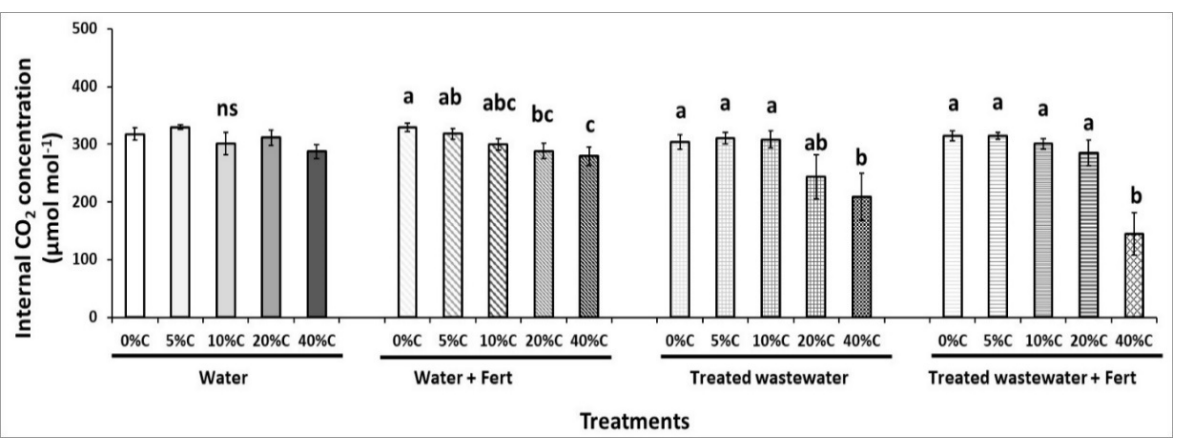

(c)

Figure 2. Cont. 


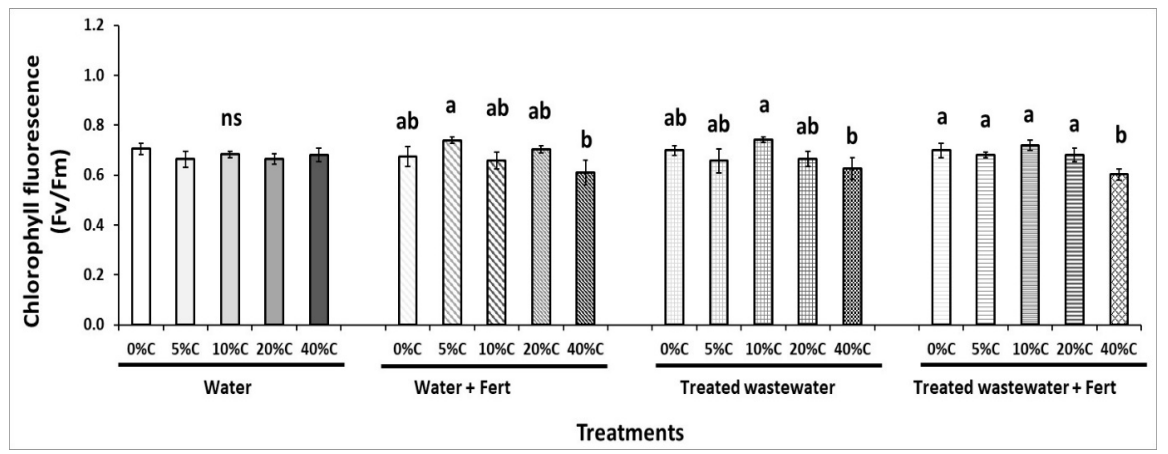

(d)

Figure 2. Effects of municipal solid waste compost (C; $0 \%-5 \%-10 \%-20 \%-40 \%)$ in soil irrigated with water (W) or treated wastewater (TWW) and with fertilizers (+Fert/-Fert) on (a) leaf photosynthetic rate $\left(\mathrm{P}_{\mathrm{n}}: \mu \mathrm{mol} \mathrm{m} \mathrm{m}^{-2} \mathrm{~s}^{-1}\right),(\mathbf{b})$ leaf stomatal conductance $\left(\mathrm{g}_{\mathrm{s}}: \mu \mathrm{mol} \mathrm{m} \mathrm{m}^{-2} \mathrm{~s}^{-1}\right)$, (c) leaf internal $\mathrm{CO}_{2}$ concentration $\left(c_{i}: \mu \mathrm{mol} \mathrm{mol}^{-1}\right)$, and $(\mathbf{d})$ chlorophyll fluorescence $(\mathrm{Fv} / \mathrm{Fm})$ in a greenhouse tomato crop. Data are means \pm SE $(n=6)$ and significant differences $(p<0.05)$ among treatments are indicated by different letters. ns: not significant.

\subsection{Effects on Leaf Element Content}

Tomato leaf nutrient content is presented in Table 3. Plants grown in $\geq 40 \% \mathrm{C}$ had higher $\mathrm{N}$ content, compared to plants grown in soil (control), while increased $\mathrm{K}$ and $\mathrm{Na}$ levels were found in plants grown in $\geq 20 \% \mathrm{C}$ in comparison to the control treatment, agreeing with previous studies on lettuce grown in different MSW compost ratios [54]. Fertigation in compost-based media increased further the accumulation of $\mathrm{N}, \mathrm{K}$, and $\mathrm{Na}$ (Table 3). Plants irrigated with TWW had higher N, K, and Na content at $\geq 40 \% \mathrm{C}$, while the combination of TWW and fertigation resulted in increased $\mathrm{N}$ (at $\geq 20 \% \mathrm{C}$ ) and $\mathrm{K}$ (at $\geq 40 \% \mathrm{C}$ ) content, compared with the relevant control. The P content did not differ among the examined treatments and ranged from 1.11 to $1.38 \mathrm{mg} \mathrm{kg}^{-1}$ dry weight. The increased mineral content from the compost addition to the soil was reported in pepper [39] and squash [15] crops. Indeed, the increased nutrient levels observed with fertigation and/or TWW application is related to the extra nutrients that fertilizers and TWW contained and that were bioavailable. Municipal wastewater contains relatively high amounts of $\mathrm{Na}$, as in the present work, and this $\mathrm{Na}$ accumulated in leaves after the TWW application. Papafilippaki et al. [60] reported that MSW compost increases the EC of soils, along with $\mathrm{Na}$ and $\mathrm{Cl}$ content in plants, and this is in line with the outcomes of the current work. The same authors reported that high Na levels in soil fail to adversely impact plant growth and yield in a salt-tolerant crop (C. spinosum); however, salt accumulation of the fertilizers with high rates of the MSW compost application did not benefit tomato yield.

Table 3. Effects of municipal solid waste compost (C; $0 \%-5 \%-10 \%-20 \%-40 \%)$ in soil irrigated with water (W) or treated wastewater (TWW) and with fertilizers (+Fert/-Fert) on leaf elemental (N, K, P, and Na in $\mathrm{mg} \mathrm{kg}^{-1}$ ) content in a greenhouse tomato crop.

\begin{tabular}{cccccc}
\hline & Compost & $\mathbf{N}$ & $\mathbf{K}$ & $\mathbf{P}$ & $\mathbf{N a}$ \\
\hline & $0 \% \mathrm{C}$ & $44.52 \pm 0.77 \mathrm{bc}$ & $51.15 \pm 0.88 \mathrm{c}$ & $1.17 \pm 0.04 \mathrm{a}$ & $8.56 \pm 0.56 \mathrm{c}$ \\
& $5 \% \mathrm{C}$ & $33.22 \pm 2.76 \mathrm{c}$ & $38.18 \pm 3.17 \mathrm{c}$ & $1.11 \pm 0.04 \mathrm{a}$ & $10.94 \pm 0.68 \mathrm{c}$ \\
Water/-Fert $(\mathrm{W})$ & $10 \% \mathrm{C}$ & $37.85 \pm 11.06 \mathrm{c}$ & $43.51 \pm 9.71 \mathrm{c}$ & $1.12 \pm 0.04 \mathrm{a}$ & $9.24 \pm 4.41 \mathrm{c}$ \\
& $20 \% \mathrm{C}$ & $61.32 \pm 5.98 \mathrm{~b}$ & $78.08 \pm 6.16 \mathrm{~b}$ & $1.17 \pm 0.05 \mathrm{a}$ & $24.17 \pm 0.91 \mathrm{~b}$ \\
& $40 \% \mathrm{C}$ & $85.54 \pm 5.56 \mathrm{a}$ & $109.99 \pm 9.66 \mathrm{a}$ & $1.16 \pm 0.02 \mathrm{a}$ & $41.47 \pm 5.13 \mathrm{a}$ \\
\hline Water/+Fert & $0 \% \mathrm{C}$ & $58.09 \pm 11.92 \mathrm{~b}$ & $66.77 \pm 13.68 \mathrm{~b}$ & $1.26 \pm 0.03 \mathrm{a}$ & $15.34 \pm 1.22 \mathrm{c}$ \\
$(\mathrm{W}+\mathrm{F})$ & $5 \% \mathrm{C}$ & $50.86 \pm 1.81 \mathrm{~b}$ & $58.46 \pm 2.08 \mathrm{~b}$ & $1.21 \pm 0.04 \mathrm{a}$ & $13.99 \pm 1.48 \mathrm{c}$ \\
& $10 \% \mathrm{C}$ & $63.32 \pm 10.11 \mathrm{~b}$ & $72.76 \pm 12.42 \mathrm{~b}$ & $1.28 \pm 0.03 \mathrm{a}$ & $24.17 \pm 4.71 \mathrm{bc}$ \\
& $20 \% \mathrm{C}$ & $63.84 \pm 8.45 \mathrm{~b}$ & $75.41 \pm 8.48 \mathrm{~b}$ & $1.21 \pm 0.02 \mathrm{a}$ & $30.95 \pm 4.81 \mathrm{~b}$ \\
& $40 \% \mathrm{C}$ & $99.52 \pm 0.25 \mathrm{a}$ & $133.93 \pm 2.91 \mathrm{a}$ & $1.18 \pm 0.01 \mathrm{a}$ & $45.88 \pm 4.33 \mathrm{a}$ \\
\hline
\end{tabular}


Table 3. Cont.

\begin{tabular}{cccccc}
\hline & Compost & $\mathbf{N}$ & $\mathbf{K}$ & $\mathbf{P}$ & Na \\
\hline & $0 \% \mathrm{C}$ & $32.64 \pm 1.51 \mathrm{~b}$ & $37.52 \pm 1.73 \mathrm{~b}$ & $1.35 \pm 0.05 \mathrm{a}$ & $49.95 \pm 7.32 \mathrm{~b}$ \\
Treated & $5 \% \mathrm{C}$ & $38.71 \pm 2.29 \mathrm{~b}$ & $44.51 \pm 2.64 \mathrm{~b}$ & $1.38 \pm 0.02 \mathrm{a}$ & $49.24 \pm 1.17 \mathrm{~b}$ \\
wastewater/-Fert & $10 \% \mathrm{C}$ & $55.49 \pm 13.01 \mathrm{ab}$ & $63.78 \pm 14.95 \mathrm{~b}$ & $1.21 \pm 0.07 \mathrm{a}$ & $52.66 \pm 6.47 \mathrm{~b}$ \\
(TWW) & $20 \% \mathrm{C}$ & $47.54 \pm 6.72 \mathrm{~b}$ & $60.79 \pm 8.67 \mathrm{~b}$ & $1.35 \pm 0.01 \mathrm{a}$ & $49.61 \pm 2.65 \mathrm{~b}$ \\
& $40 \% \mathrm{C}$ & $76.98 \pm 7.99 \mathrm{a}$ & $98.69 \pm 11.65 \mathrm{a}$ & $1.32 \pm 0.09 \mathrm{a}$ & $86.93 \pm 5.61 \mathrm{a}$ \\
\hline & $0 \% \mathrm{C}$ & $32.45 \pm 5.65 \mathrm{~b}$ & $38.85 \pm 7.61 \mathrm{~b}$ & $1.31 \pm 0.08 \mathrm{a}$ & $48.61 \pm 12.65 \mathrm{a}$ \\
Treated & $5 \% \mathrm{C}$ & $49.42 \pm 5.94 \mathrm{ab}$ & $56.81 \pm 6.82 \mathrm{ab}$ & $1.21 \pm 0.02 \mathrm{a}$ & $48.59 \pm 8.84 \mathrm{a}$ \\
wastewater/+Fert & $10 \% \mathrm{C}$ & $55.21 \pm 2.79 \mathrm{ab}$ & $63.95 \pm 3.21 \mathrm{ab}$ & $1.36 \pm 0.04 \mathrm{a}$ & $47.91 \pm 4.41 \mathrm{a}$ \\
(TWW+F) & $20 \% \mathrm{C}$ & $61.86 \pm 4.26 \mathrm{a}$ & $71.09 \pm 4.89 \mathrm{ab}$ & $1.27 \pm 0.09 \mathrm{a}$ & $63.18 \pm 8.32 \mathrm{a}$ \\
& $40 \% \mathrm{C}$ & $65.16 \pm 9.41 \mathrm{a}$ & $84.06 \pm 11.62 \mathrm{a}$ & $1.18 \pm 0.07 \mathrm{a}$ & $57.41 \pm 9.45 \mathrm{a}$ \\
\hline
\end{tabular}

Values $(n=4)$ in columns followed by the same letter for each water/fertilizer applications are not significantly different. $p \leq 0.05$.

\subsection{Effect on Fruit Quality}

Fruit fresh weight was unaffected by the ratio of the compost used in the growing media but changed when plants were subjected to fertigation and/or irrigation with TWW (Figure 1). Therefore, fruit fresh weight was significantly $(p<0.05$ ) decreased (up to $32.2 \%$ ) in plants grown in $\geq 40 \%$ C+Fert, decreased (up to $24.6 \%$ ) in plants grown in $\geq 40 \%$ C+TWW, and decreased (up to $30.4 \%$ ) in plants subjected to $\geq 40 \% \mathrm{C}+\mathrm{TWW}+$ Fert when compared with the relevant control treatment. Similar findings were observed in pepper crops cultivated in a high ratio of MSW compost [11] and pepper crops irrigated with TWW with additional fertilizers [39]. This indicates that the increased nutrition that was obtained either by high rates of compost or by using treated wastewater with fertilizers negatively affected fruit fresh weight. Fruit size varied among the different treatments (Figure 3). Fruit length and diameter decreased at high compost ratio $(\geq 40 \% \mathrm{C})$ used in the growing media with fertilizers and/or TWW applications, compared to the control treatment. Fruit diameter increased at $5 \% \mathrm{C}$ in plants subjected to fertilizers ( $5 \% \mathrm{C}+\mathrm{Fert})$, compared to the relevant control $(0 \% \mathrm{C}+\mathrm{Fert})$. Uniform fruit size is of importance for marketability of the produce, but most importantly for the postharvest storage and management of the fresh commodities.

Fruit color was less affected by the examined treatments as presented in Table 4, while no differences were found in fruit color $\left(L^{*}, a^{*}, b^{*}\right.$ and color index $\left.(\mathrm{CI})\right)$ in different compost-based media. Tomato redness (color $a^{*}$ ) was increased at $\geq 20 \% \mathrm{C}+\mathrm{Fert}$, compared with the control and $5 \% \mathrm{C}+\mathrm{Fert}$. Fruit lightness $\left(L^{*}\right)$ and color $b^{*}$ were increased but color index was decreased at $\leq 5 \% \mathrm{C}+\mathrm{TWW}+\mathrm{Fert}$. 


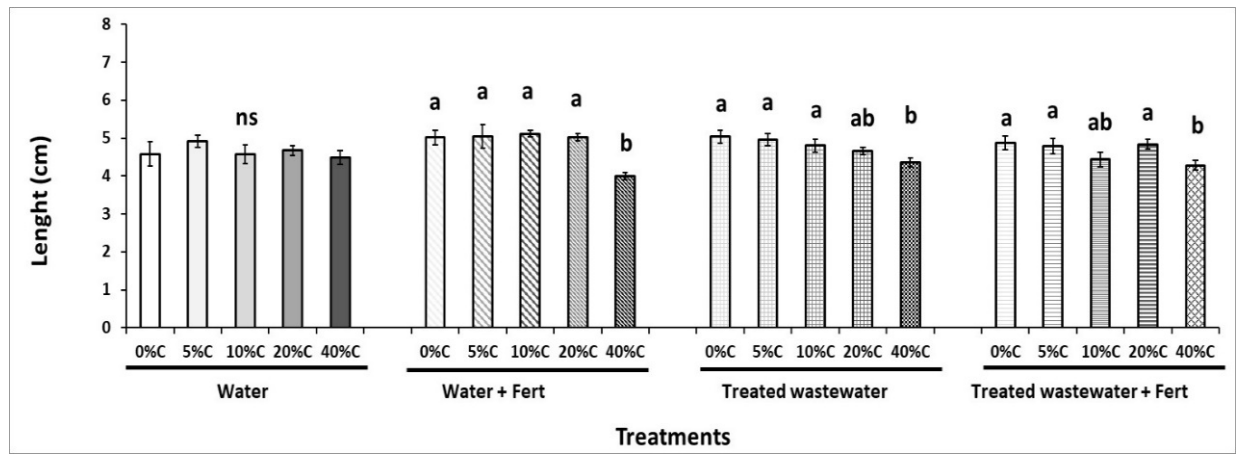

(a)

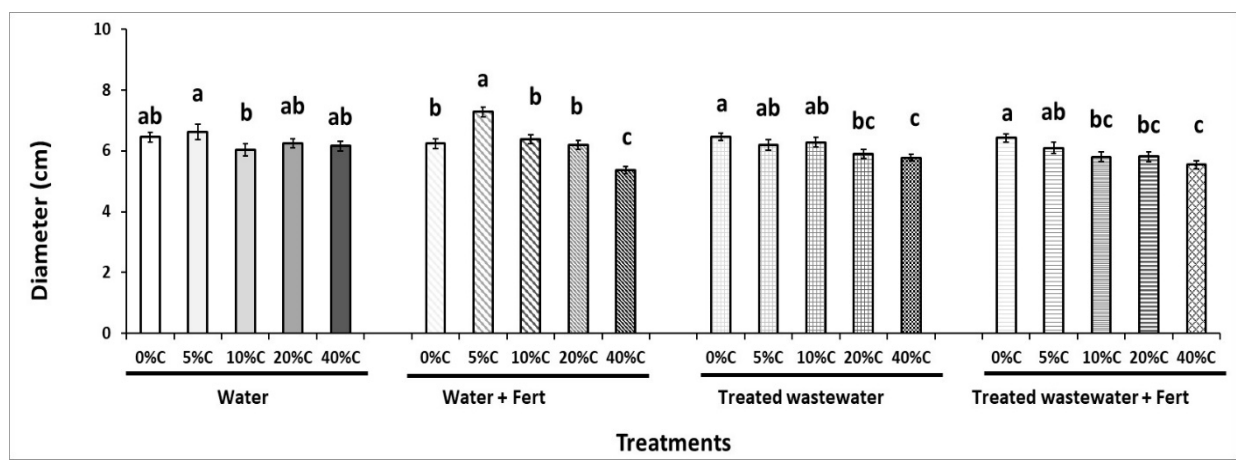

(b)

Figure 3. Effects of municipal solid waste compost (C; $0 \%-5 \%-10 \%-20 \%-40 \%$ ) in soil irrigated with water (W) or treated wastewater (TWW) and with fertilizers (+Fert/-Fert) on fruit size [(a) length and (b) diameter in $\mathrm{cm}$ ] in a greenhouse tomato crop. Data are means $\pm \mathrm{SE}(\mathrm{n}=$ at least 30$)$ and significant differences $(p<0.05)$ among treatments are indicated by different letters. ns: not significant.

Table 4. Effects of municipal solid waste compost (C; 0\%-5\%-10\%-20\%-40\%) in soil irrigated with water (W) or treated wastewater (TWW) and with fertilizers (+Fert/-Fert) on fruit color $\left(L^{*}, a^{*}, b^{*}\right.$, color index) in a greenhouse tomato crop.

\begin{tabular}{cccccc}
\hline & Compost & Color $\boldsymbol{L}^{*}$ & Color $\boldsymbol{a}^{*}$ & Color $\boldsymbol{b}^{*}$ & Color Index \\
\hline & $0 \% \mathrm{C}$ & $34.76 \pm 0.92 \mathrm{a}$ & $18.38 \pm 0.79 \mathrm{a}$ & $15.29 \pm 1.18 \mathrm{a}$ & $33.88 \pm 2.19 \mathrm{a}$ \\
Water/-Fert $(\mathrm{W})$ & $5 \% \mathrm{C}$ & $38.01 \pm 2.20 \mathrm{a}$ & $16.24 \pm 2.66 \mathrm{a}$ & $17.11 \pm 2.04 \mathrm{a}$ & $31.32 \pm 4.76 \mathrm{a}$ \\
& $10 \% \mathrm{C}$ & $35.61 \pm 0.85 \mathrm{a}$ & $15.47 \pm 0.91 \mathrm{a}$ & $14.99 \pm 0.91 \mathrm{a}$ & $30.26 \pm 2.12 \mathrm{a}$ \\
& $20 \% \mathrm{C}$ & $36.49 \pm 0.98 \mathrm{a}$ & $17.39 \pm 2.12 \mathrm{a}$ & $14.61 \pm 0.73 \mathrm{a}$ & $32.45 \pm 4.24 \mathrm{a}$ \\
& $40 \% \mathrm{C}$ & $36.48 \pm 1.01 \mathrm{a}$ & $16.56 \pm 1.72 \mathrm{a}$ & $15.14 \pm 0.93 \mathrm{a}$ & $34.57 \pm 3.61 \mathrm{a}$ \\
\hline & $0 \% \mathrm{C}$ & $36.71 \pm 0.88 \mathrm{a}$ & $16.81 \pm 1.18 \mathrm{~b}$ & $16.38 \pm 0.98 \mathrm{a}$ & $30.59 \pm 2.71 \mathrm{a}$ \\
Water/+Fert & $5 \% \mathrm{C}$ & $35.06 \pm 1.36 \mathrm{a}$ & $16.78 \pm 1.72 \mathrm{~b}$ & $13.82 \pm 0.78 \mathrm{a}$ & $37.45 \pm 3.63 \mathrm{a}$ \\
(W+F) & $10 \% \mathrm{C}$ & $35.71 \pm 0.69 \mathrm{a}$ & $18.79 \pm 0.77 \mathrm{ab}$ & $16.08 \pm 1.01 \mathrm{a}$ & $34.83 \pm 2.25 \mathrm{a}$ \\
& $20 \% \mathrm{C}$ & $35.62 \pm 0.67 \mathrm{a}$ & $20.51 \pm 0.52 \mathrm{a}$ & $15.34 \pm 0.89 \mathrm{a}$ & $38.46 \pm 2.72 \mathrm{a}$ \\
& $40 \% \mathrm{C}$ & $36.02 \pm 0.63 \mathrm{a}$ & $20.32 \pm 0.82 \mathrm{a}$ & $15.61 \pm 0.87 \mathrm{a}$ & $37.56 \pm 2.12 \mathrm{a}$ \\
\hline & $0 \% \mathrm{C}$ & $34.85 \pm 0.93 \mathrm{a}$ & $17.76 \pm 0.85 \mathrm{a}$ & $15.16 \pm 1.06 \mathrm{ab}$ & $38.36 \pm 2.06 \mathrm{a}$ \\
Treated & $5 \% \mathrm{C}$ & $34.15 \pm 0.57 \mathrm{a}$ & $18.47 \pm 0.77 \mathrm{a}$ & $13.02 \pm 0.32 \mathrm{~b}$ & $42.96 \pm 1.82 \mathrm{a}$ \\
wastewater/-Fert & $10 \% \mathrm{C}$ & $34.74 \pm 0.73 \mathrm{a}$ & $19.66 \pm 0.49 \mathrm{a}$ & $14.11 \pm 0.91 \mathrm{ab}$ & $39.55 \pm 3.46 \mathrm{a}$ \\
(TWW) & $20 \% \mathrm{C}$ & $36.20 \pm 0.71 \mathrm{a}$ & $19.96 \pm 1.33 \mathrm{a}$ & $15.75 \pm 0.78 \mathrm{a}$ & $37.41 \pm 2.86 \mathrm{a}$ \\
& $40 \% \mathrm{C}$ & $34.20 \pm 0.44 \mathrm{a}$ & $20.92 \pm 0.69 \mathrm{a}$ & $13.51 \pm 0.46 \mathrm{~b}$ & $44.64 \pm 1.77 \mathrm{a}$ \\
\hline & $0 \% \mathrm{C}$ & $35.14 \pm 0.68 \mathrm{a}$ & $19.77 \pm 0.56 \mathrm{a}$ & $15.78 \pm 0.86 \mathrm{a}$ & $36.36 \pm 2.21 \mathrm{~b}$ \\
Treated & $5 \% \mathrm{C}$ & $36.84 \pm 0.69 \mathrm{a}$ & $20.49 \pm 0.52 \mathrm{a}$ & $16.87 \pm 0.92 \mathrm{a}$ & $34.41 \pm 2.02 \mathrm{~b}$ \\
wastewater/+Fert & $10 \% \mathrm{C}$ & $35.24 \pm 0.91 \mathrm{ab}$ & $19.01 \pm 1.08 \mathrm{a}$ & $14.37 \pm 0.74 \mathrm{ab}$ & $41.59 \pm 2.98 \mathrm{a}$ \\
(TWW+F) & $20 \% \mathrm{C}$ & $35.26 \pm 0.67 \mathrm{ab}$ & $19.59 \pm 0.71 \mathrm{a}$ & $14.74 \pm 0.97 \mathrm{ab}$ & $38.67 \pm 2.09 \mathrm{ab}$ \\
& $40 \% \mathrm{C}$ & $34.63 \pm 0.46 \mathrm{~b}$ & $19.25 \pm 0.57 \mathrm{a}$ & $13.75 \pm 0.57 \mathrm{~b}$ & $42.01 \pm 2.01 \mathrm{a}$ \\
\hline
\end{tabular}

Values $(\mathrm{n}=$ at least 15$)$ in columns followed by the same letter for each water/fertilizer applications are not significantly different. $p \leq 0.05$. 
Fruit firmness was maintained in fruits from plants grown in $\geq 20 \%$ C, compared to the control and $5 \% \mathrm{C}$ treatment, while fertigation alleviated these changes and firmness remained at similar levels (averaged as $2.67 \mathrm{~N}$ ) among treatments (Figure 4). Fruits harvested from plants grown with TWW and/or fertigation did not show a specific trend in their firmness. Fruit firmness maintenance prolongs storage for the commodity and maintains the quality of the fruit, as tomato is a climacteric fruit and can still ripen after harvest [61]. Total soluble solids increased in fruits harvested from plants grown in high compost ratios or subjected to fertigation and/or TWW (Figure 4). TSS were increased (up to $60 \%$ ) at $\geq 20 \% \mathrm{C}$ when compared to the control (soil) or low compost-based media. Similarly, TSS increased up to $32.7 \%, 22.4 \%$, and $30.4 \%$ at $40 \%$ C+Fert, $40 \%$ C+TWW, and $40 \%$ C+TWW+Fert, respectively, compared to the relevant control. Titratable acidity had a similar trend with TSS for plants grown in soil and C-based media and irrigated (or fertigated) with tap water, and this resulted in an unchanged ripening index (i.e., similar TSS/TA ratio). In case of TWW+Fert applications, the TSS/TA followed the TSS trend (i.e., increased values at the high compost ratio). Hargreaves et al. [62] reported that sweetness indicated by the TSS/TA ratio in strawberries was unaffected by the different MSW compost levels, agreeing with the present findings. Ascorbic acid of tomatoes increased at $\geq 20 \% \mathrm{C}$ and decreased at $\geq 20 \% \mathrm{C}+$ Fert treatments (Figure 5). However, in cases of TWW and/or Fert, ascorbic acid revealed the highest levels at $5 \%$ of compost-based media. In previous studies, irrigation with treated wastewater did not affect tomato fruit fresh weight, TSS, titratable acidity, and dry matter content [32]. In contrast Al-Lahham et al. [63] reported a decrease of $1.5 \%$ in the TSS, $5.78 \mathrm{~N}$ in firmness, and $5.1 \%$ in weight loss of tomato fruit following TWW application. Total phenols content increased at $\geq 20 \% \mathrm{C}$ and decreased at the $20 \% \mathrm{C}+$ Fert treatment, compared with the control. Interestingly, when TWW and fertigation were combined, total phenols content was higher in $5 \%-10 \%$ compost-based media. Dagianta et al. [39] reported that total phenols content decreased (up to 41\%) in peppers harvested from plants grown in substrate with $>20 \% \mathrm{C}$. Fresh produce of high phenolic levels is appreciated because of the correlated higher antioxidant activity, which protects tissue oxidation by scavenging free radicals and inhibiting lipid peroxidation, and thereby advancing the nutritional quality of the fresh produce [64]. 


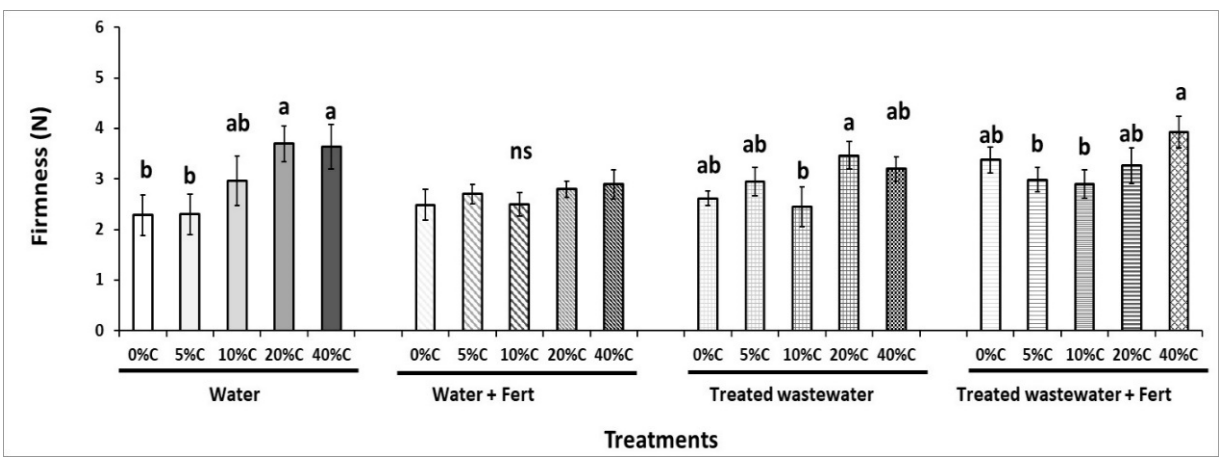

(a)

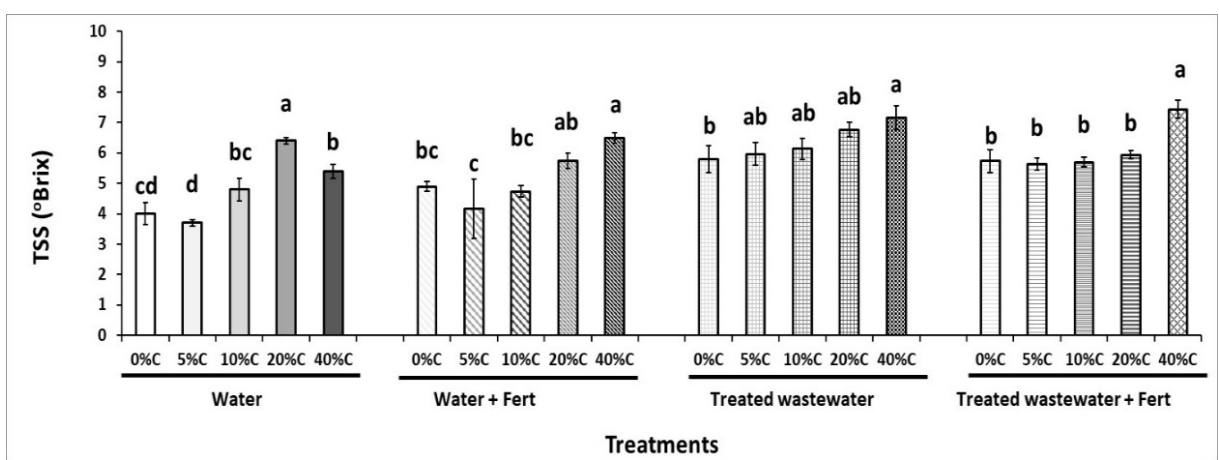

(b)

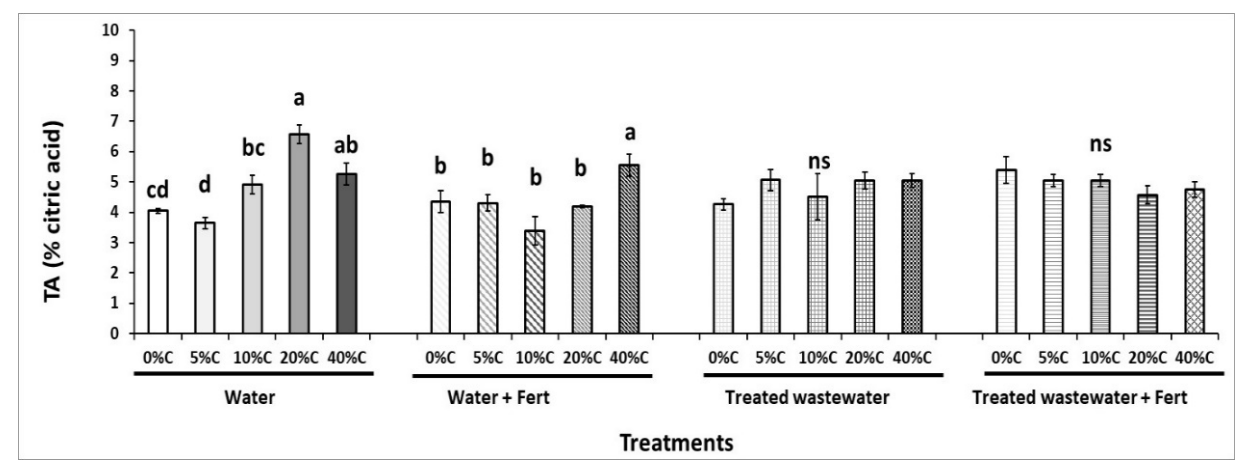

(c)

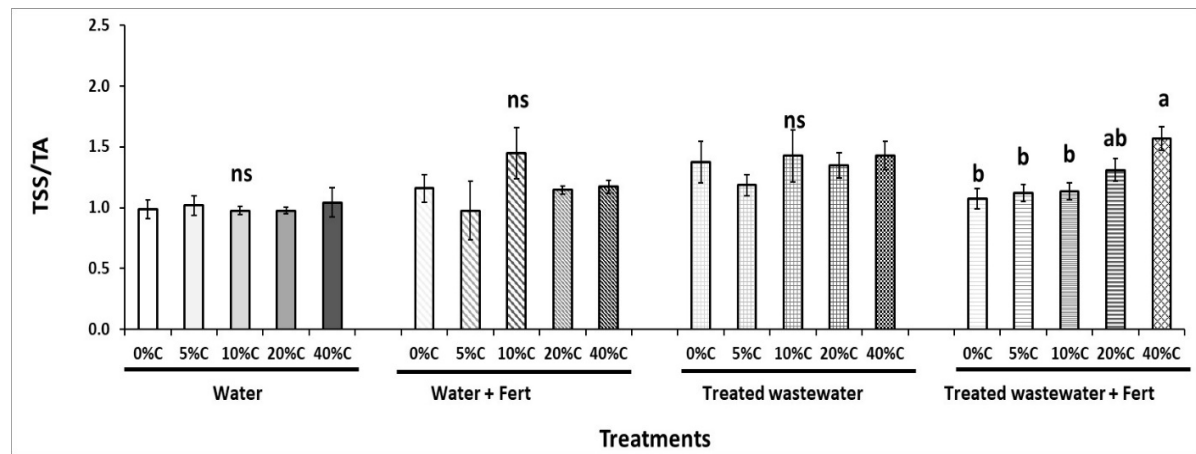

(d)

Figure 4. Effects of municipal solid waste compost (C; $0 \%-5 \%-10 \%-20 \%-40 \%$ ) in soil irrigated with water (W) or treated wastewater (TWW) and with fertilizers (+Fert/-Fert) on (a) fruit firmness (N), (b) total soluble solids (TSS; in ${ }^{\circ}$ Brix), (c) titratable acidity (TA; in \% of citric acid) and (d) the ripening index (TSS/TA) in a greenhouse tomato crop. Data are means \pm SE $(n=12)$ and significant differences $(p<0.05)$ among treatments are indicated by different letters. ns: not significant. 


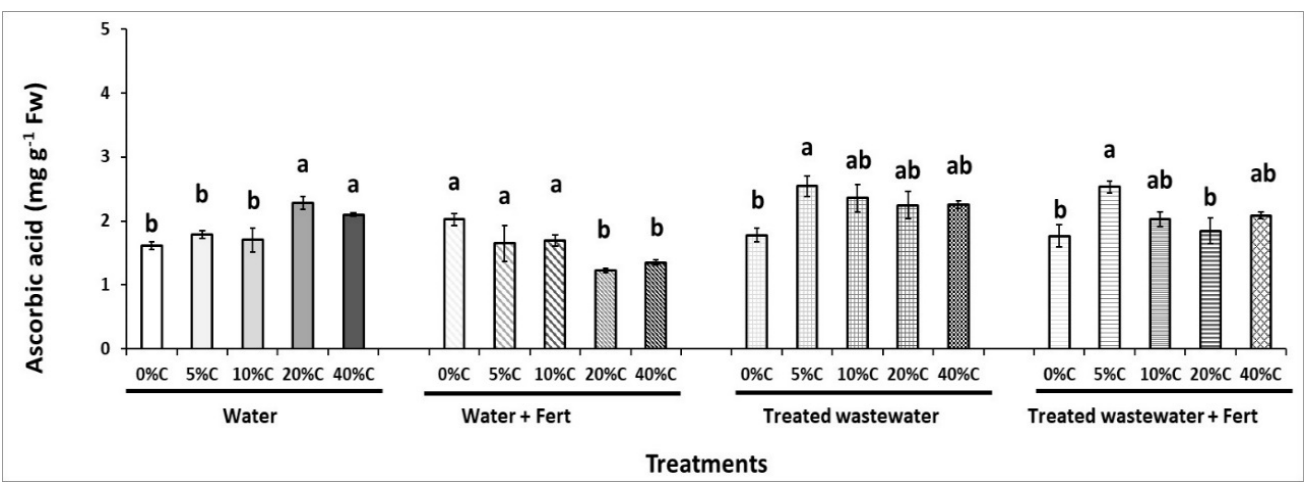

(a)

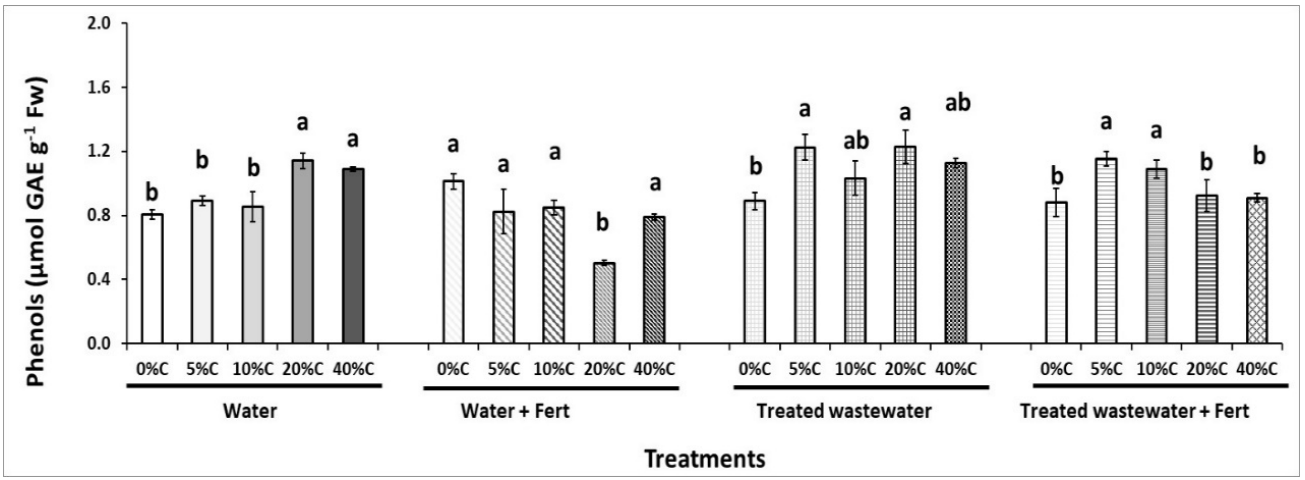

(b)

Figure 5. Effects of municipal solid waste compost (C; $0 \%-5 \%-10 \%-20 \%-40 \%$ ) in soil irrigated with water (W) or treated wastewater (TWW) and with fertilizers (+Fert/-Fert) on fruit (a) ascorbic acid $\left(\mathrm{mg} \mathrm{g}^{-1} \mathrm{Fw}\right)$ and $(\mathbf{b})$ total phenolics ( $\mu \mathrm{mol} \mathrm{GAE} \mathrm{g}^{-1}$ fresh weight-Fw) in a greenhouse tomato crop. Data are means \pm SE $(n=12)$ and significant differences $(p<0.05)$ among treatments are indicated by different letters. ns: not significant.

Taking into consideration the scale (out of 4 units) of fruit marketability, with higher values reflecting lower marketability (i.e., malformation, wounds, infection), it was observed that decreased marketability, symptoms of blossom end rot (BER), malformation, and cracking were observed at $40 \%$ $\mathrm{C}$ (Figure 6), being in agreement with previous results from pepper crops grown in MSW compost [11]. Similar observations were found in the case of $40 \% \mathrm{C}+\mathrm{TWW}+\mathrm{Fert}$ treatment. Less marketable produce, malformation, and BER symptoms were also higher at 40\% C+Fert and 40\% C+TWW, while cracking was increased at the equivalent $5 \%$ of compost $(5 \% \mathrm{C}+$ Fert and $5 \% \mathrm{C}+\mathrm{TWW})$. 

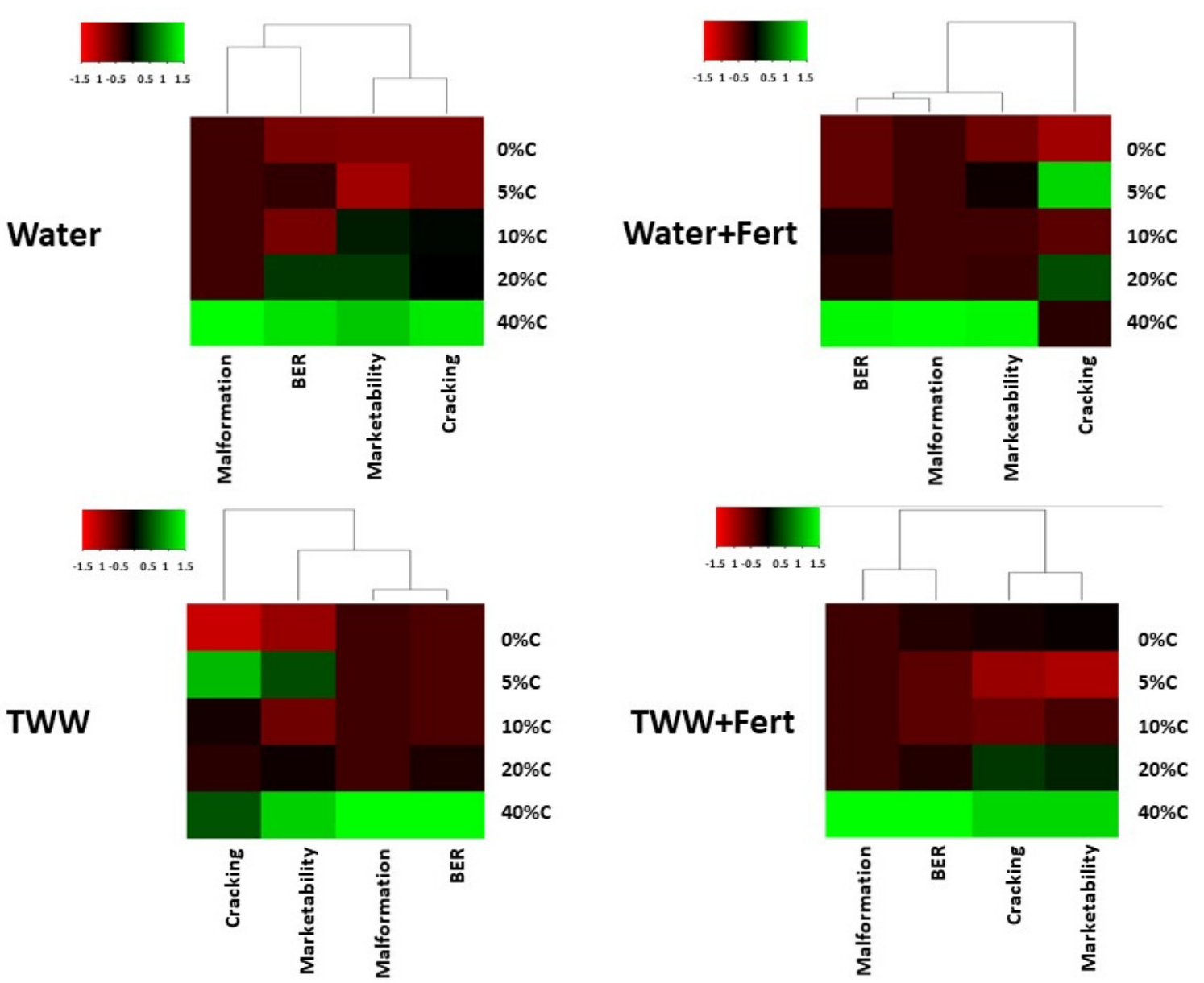

Figure 6. Effects of municipal solid waste compost (C; 0\%-5\%-10\%-20\%-40\%) in soil irrigated with water (W) or treated wastewater (TWW) and with fertilizers (+Fert/-Fert) on marketability, blossom end rot (BER), cracking, and malformation of tomato fruit in a greenhouse tomato crop. Red shades indicate lower levels (less than -1.5-fold), deep red corresponds to -1-fold, black signifies that the level is not different from the control, deep green corresonds to 1-fold, clear green indicates that the level is more than 1.5 higher than the control. Values are expressed in percentage.

Fruits harvested from plants grown in soil and compost-based media irrigated with tap water did not differ on total coliform units, while E. coli was absent (Figure 7). However, when plants were irrigated with TWW, total coliforms increased ( 2.7 times) at $40 \%$ C, compared with $\leq 10 \% \mathrm{C}$ and soil treatment, and this was also reflected by the increased E. coli values (1.34 CFU $100 \mathrm{~g}^{-1}$ of fresh weight). When TWW was combined with fertigation, there were no differences in total coliform and $E$. coli among the examined compost-based media. However, the maximum load that was found in $40 \%$ C+TWW and averaged $5.79 \mathrm{CFU} 100 \mathrm{~g}^{-1}$ of fresh weight for total coliforms appeared lower than the levels reported by Cirelli et al. [32] in tomato and eggplant. The presence of E. coli in pepper, eggplant, and tomato crops irrigated with TWW was reported previously [32,39]. Selected fruits were tested for infection from bacteria entering the fruit and were found to be not contaminated (data not shown), indicating that bacteria did not pass through the tissue of the plant. However, this fact needs to be looked at more closely in the future, eliminating any splashing and possible transfer of bacteria on and inside the fruit, before arriving at any final conclusions. Cirelli et al. [32] reported that tomato and eggplant fruit that were in contact with soil or plastic cover material had increased microbial load, compared with the fruits that had no contact with soil; they had negligible or no microbial amount. Noticeably, the bacteria load in the soil was almost 1000 times higher than that on fruits, being in line with previous studies on tomato and cucumber [29] and pepper [39] crops irrigated with tertiary-treated wastewater. Application of wastewater in tomato crops led to increased microbial 
contamination (E. coli and fecal streptococci) on the surface of the soil [33]. Utilization of untreated municipal wastewater for irrigation purposes is associated with a high number of risks, affecting crop yield and quality but also increasing the levels of pathogens, as it may be highly contaminated [65]. To that point, treating wastewater is important for improving its quality and safety $[28,65]$.

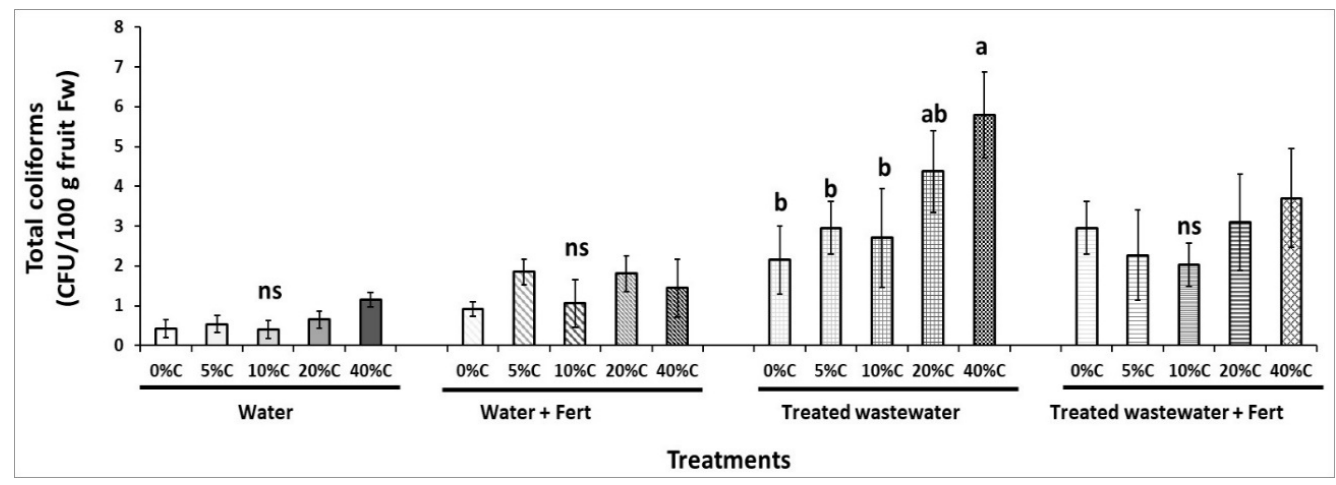

(a)

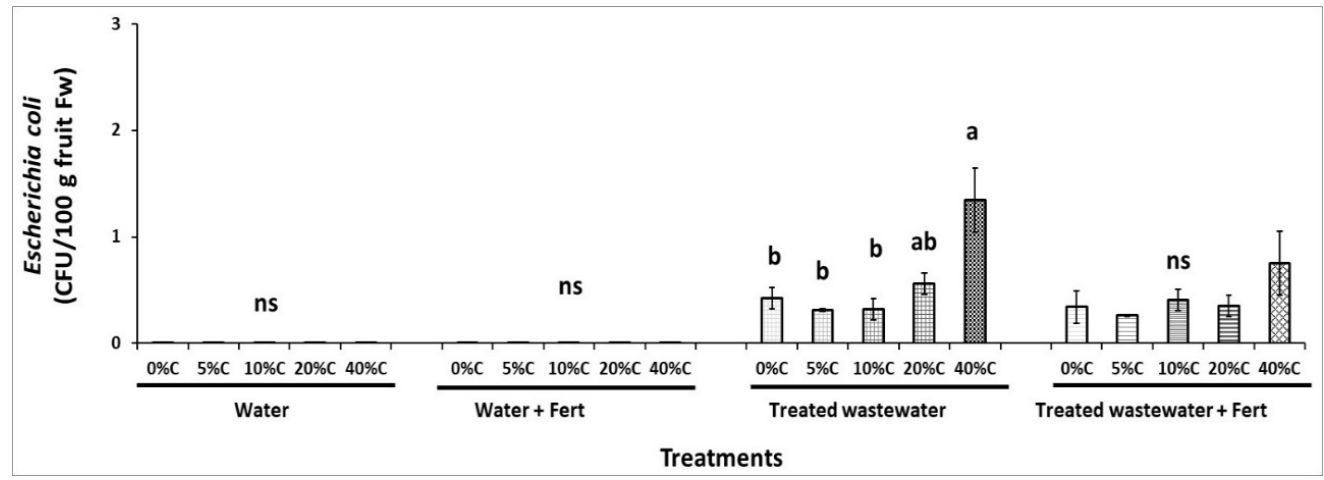

(b)

Figure 7. Effects of municipal solid waste compost (C; $0 \%-5 \%-10 \%-20 \%-40 \%)$ in soil irrigated with water (W) or treated wastewater (TWW) and with fertilizers (+Fert/-Fert) on bacteria [(a) total coliform and (b) Escherichia coli] units (CFU/100 $\mathrm{g}$ fruit $\mathrm{fw}$ ) on the fruits in a greenhouse tomato crop. Data are means \pm SE $(n=23)$ and significant differences $(p<0.05)$ among treatments are indicated by different letters. ns: not significant.

One risk of using MSW compost is the potential accumulation of heavy metals that could have negative effects on the environment [7]. However, the risk of the presence of heavy metals in the food chain is negligible, as reported in four lettuce cultivars grown in MSW compost-based media [66]. Municipal wastewater irrigation in a controlled manner is considered to be environmentally friendly. Wastewater management practices help to reduce ecosystem contamination from the direct drainage of wastewater into surface or groundwater [67]. Furthermore, wastewater is a valuable source of plant nutrients (exchangeable $\mathrm{Na}, \mathrm{K}, \mathrm{Ca}, \mathrm{Mg}$, and $\mathrm{P}$ ) and organic matter, which are required to maintain the fertility and productivity of arid soils. However, the microbial load present in wastewater may have a negative impact on plant growth and yield. The use of TWW for production of vegetables, considered as edible fresh produce, requires more exploitation. In addition, the negligible microbial contamination of pepper fruit indicated the possible use of TWW in agriculture [39]. However, the treated wastewater can be an alternative means of irrigation in vegetables, i.e., tomatoes, to be consumed after cooking but not taken as raw, provided the contingency of the effluent is controlled continuously to avoid contamination [63]. Cirelli et al. [32] reported that tomato and eggplant fruits that were in contact with soil or plastic had increased fecal coliform, fecal streptococci, E. coli (only for tomato), but Salmonella was absent; whereas fruits not in contact with soil revealed negligible or no amounts. Therefore, alternative cultivation practices might be required when the plants are irrigated with TWW, by modifying the 
pruning and fruit thinning, as the first fruits could be produced at higher levels of the plant (considering the vertical plant growth system), compared to soil. In this case, any TWW splashing of fruits can be minimized. The present findings can have a wide validity in vegetable crops such as cucumber, pepper, eggplant, etc., by considering an intensive cultivation scheme in greenhouses and pruning cultivation practices applied by the farmer.

\section{Conclusions}

The application of municipal solid waste compost and treated wastewater in agriculture is gaining increased interest, as both can not only be effective ways of waste management and recycling, but also mineral sources for crop needs. However, the safety of their use in agriculture was discussed because of concerns about their levels of salts, heavy metals, and microbial load. In the present study, compost increased the physiochemical properties and mineral content of the substrates, while fertigation and TWW contributed mostly to the latter. The increased mineral levels in the substrate were reflected in the increased levels of $\mathrm{N}, \mathrm{K}$, and $\mathrm{Na}$ in tomato leaves. Compost up to $20 \%$ was demonstrated to be a suitable soil amendment for crop production, while a greater ratio (i.e., $40 \% \mathrm{C}$ ) possibly caused salt accumulation in the soil and negatively affected crop production. The combination of compost with fertigation and/or TWW supported further tomato growth and yield; positive effects were mainly observed when low compost levels were applied combined with fertigation and/or TWW. This highlights the importance of compost ratio adjustment according to the compost EC levels. Fruit quality as indicated by increased TSS, TA, ascorbic acid and total phenolics benefited from the high ratios of compost and/or fertigation and TWW, but marketability did not. Microbial load after the use of TWW is of consideration, as high levels can be present on the substrate but lower levels can be found on the fruit, mainly due to splashing or fruit contact with the soil, indicating the importance of reconsidering the current cultivation practices applied to tomatoes, especially the adapted pruning system.

Supplementary Materials: The following are available online at http://www.mdpi.com/2071-1050/12/10/4287/s1, Table S1. Correlations coefficients and ( $p$-values) between compost, fertilizer and treated wastewater (TWW) with tomato attributes.

Author Contributions: Conceptualization, A.C. and N.T.; methodology, C.S., A.C. and N.T.; software, A.C.; validation, A.C. and N.T.; formal analysis, C.S., A.C. and N.T.; investigation, C.S., A.C. and N.T.; resources, N.T.; data curation, C.S., A.C. and N.T.; writing-original draft preparation, A.C. and N.T.; writing-review and editing, A.C. and N.T.; visualization, A.C.; supervision, N.T.; project administration, N.T.; funding acquisition, N.T. All authors have read and agreed to the published version of the manuscript.

Funding: This work was funded by the Cyprus University of Technology Open Access Author Fund.

Acknowledgments: The authors are thankful to the solid waste and wastewater management lab (Technological Educational Institute of Crete, Greece) and the Inter-Municipal Enterprise for the Management of Solid Wastes of Chania, Greece, for the TWW and compost supply, respectively.

Conflicts of Interest: The authors declare no conflict of interest.

\section{References}

1. Meena, M.D.; Yadav, R.K.; Narjary, B.; Yadav, G.; Jat, H.S.; Sheoran, P.; Meena, M.K.; Antil, R.S.; Meena, B.L.; Singh, H.V.; et al. Municipal solid waste (MSW): Strategies to improve salt affected soil sustainability: A review. Waste Manag. 2019, 84, 38-53. [CrossRef] [PubMed]

2. Eurostat Yearbook. The Statistical Guide to Europe; European Communities: Luxembourg, 2017.

3. Naveen, B.P.; Sumalatha, J.; Malik, R.K. A study on contamination of ground and surface water bodies by leachate leakage from a landfill in Bangalore, India. Int. J. Geo-Eng. 2018, 9, 27. [CrossRef]

4. Moldes, A.; Cendón, Y.; Barral, M.T. Evaluation of municipal solid waste compost as a plant growing media component, by applying mixture design. Bioresour. Technol. 2007, 98, 3069-3075. [CrossRef] [PubMed]

5. Pecorini, I.; Peruzzi, E.; Albini, E.; Doni, S.; Macci, C.; Masciandaro, G.; Iannelli, R. Evaluation of MSW Compost and Digestate Mixtures for a Circular Economy Application. Sustainability 2020, 12, 3042. [CrossRef] 
6. Ribeiro, H.M.; Romero, A.M.; Pereira, H.; Borges, P.; Cabral, F.; Vasconcelos, E. Evaluation of a compost obtained from forestry wastes and solid phase of pig slurry as a substrate for seedlings production. Bioresour. Technol. 2007, 98, 3294-3297. [CrossRef]

7. Hargreaves, J.C.; Adl, M.S.; Warman, P.R. A review of the use of composted municipal solid waste in agriculture. Agric. Ecosyst. Environ. 2008, 123, 1-14. [CrossRef]

8. Karak, T.; Paul, R.K.; Sonar, I.; Sanyal, S.; Ahmed, K.Z.; Boruah, R.K.; Das, D.K.; Dutta, A.K. Chromium in soil and tea (Camellia sinensis L.) infusion: Does soil amendment with municipal solid waste compost make sense? Food Res. Int. 2014, 64, 114-124. [CrossRef]

9. Zhong, W.; Gu, T.; Wang, W.; Zhang, B.; Lin, X.; Huang, Q.; Shen, W. The effects of mineral fertilizer and organic manure on soil microbial community and diversity. Plant Soil 2010, 326, 511-522. [CrossRef]

10. Wei, Y.; Zhao, Y.; Xi, B.; Wei, Z.; Li, X.; Cao, Z. Changes in phosphorus fractions during organic wastes composting from different sources. Bioresour. Technol. 2015, 189, 349-356. [CrossRef]

11. Tzortzakis, N.; Gouma, S.; Dagianta, E.; Saridakis, C.; Papamichalaki, M.; Goumas, D.; Manios, T. Use of fertigation and municipal solid waste compost for greenhouse pepper cultivation. Sci. World J. 2012, 2012, 1-8. [CrossRef]

12. Zeng, G.; Wu, H.; Liang, J.; Guo, S.; Huang, L.; Xu, P.; Liu, Y.; Yuan, Y.; He, X.; He, Y. Efficiency of biochar and compost (or composting) combined amendments for reducing $\mathrm{Cd}, \mathrm{Cu}, \mathrm{Zn}$ and $\mathrm{Pb}$ bioavailability, mobility and ecological risk in wetland soil. RSC Adv. 2015, 5, 34541-34548. [CrossRef]

13. Bernal, M.P.; Alburquerque, J.A.; Moral, R. Composting of animal manures and chemical criteria for compost maturity assessment. A review. Bioresour. Technol. 2009, 100, 5444-5453. [CrossRef] [PubMed]

14. Paradelo, R.; Villada, A.; Devesa-Rey, R.; Moldes, A.B.; Domínguez, M.; Patiño, J.; Barral, M.T. Distribution and availability of trace elements in municipal solid waste composts. J. Environ. Monit. 2011, 13, $201-211$. [CrossRef] [PubMed]

15. Warman, P.R.; Rodd, A.V.; Hicklenton, P. The effect of MSW compost and fertilizer on extractable soil elements and the growth of winter squash in Nova Scotia. Agric. Ecosyst. Environ. 2009, 133, 98-102. [CrossRef]

16. Ozores-Hampton, M.; Hanlon, E.; Bryan, H.; Schaffer, B. Cadmium, copper, lead, nickel and zinc concentrations in tomato and squash grown in msw compost-amended calcareous soil. Compos. Sci. Util. 1997, 5, 40-45. [CrossRef]

17. Ribeiro, H.M.; Vasconcelos, E.; dos Santos, J.Q. Fertilisation of potted geranium with a municipal solid waste compost. Bioresour. Technol. 2000, 73, 247-249. [CrossRef]

18. Castillo, J.E.; Herrera, F.; López-Bellido, R.J.; López-Bellido, F.J.; López-Bellido, L.; Fernández, E.J. Municipal solid waste (msw) compost as a tomato transplant medium. Compos. Sci. Util. 2004, 12, 86-92. [CrossRef]

19. Chrysargyris, A.; Tzortzakis, N. Municipal solid wastes and mineral fertilizer as an eggplant transplant medium. J. Soil Sci. Plant Nutr. 2015, 15, 11-23. [CrossRef]

20. Papamichalaki, M.; Papadaki, A.; Tzortzakis, N. Substitution of peat with municipal solid waste compost in watermelon seedling production combined with fertigation. Chil. J. Agric. Res. 2014, 74, 452-459. [CrossRef]

21. Chrysargyris, A.; Stamatakis, A.; Moustakas, K.; Prasad, M.; Tzortzakis, N. Evaluation of Municipal Solid Waste Compost and/or Fertigation as Peat Substituent for Pepper Seedlings Production. Waste Biomass Valorization 2018, 9, 2285-2294. [CrossRef]

22. Al Mamun, S.; Chanson, G.; Muliadi, M.; Benyas, E.; Aktar, M.; Lehto, N.; McDowell, R.; Cavanagh, J.; Kellermann, L.; Clucas, L.; et al. Municipal composts reduce the transfer of Cd from soil to vegetables. Environ. Pollut. 2016, 213, 8-15. [CrossRef] [PubMed]

23. Bostani, A. How amending calcareous soils with municipal solid waste compost affects Fe fractionation and availability to plant. J. Trace Elem. Med. Biol. 2018, 47, 149-155. [CrossRef] [PubMed]

24. Leszczyńska, D.; Kwiatkowska-Malina, J. The influence of organic matter on yield and quality of winter wheat Triticum aestivum ssp. vulgare (L.) cultivated on soils contaminated with heavy metals. Ecol. Chem. Eng. S 2013, 20, 701-708.

25. Kalavrouziotis, I.K.; Kokkinos, P.; Oron, G.; Fatone, F.; Bolzonella, D.; Vatyliotou, M.; Fatta-Kassinos, D.; Koukoulakis, P.H.; Varnavas, S.P. Current status in wastewater treatment, reuse and research in some mediterranean countries. Desalin. Water Treat. 2015, 53, 2015-2030. [CrossRef]

26. Ilias, A.; Panoras, A.; Angelakis, A. Wastewater recycling in Greece: The case of Thessaloniki. Sustainability 2014, 6, 2876-2892. [CrossRef] 
27. Chen, W.; Bai, Y.; Zhang, W.; Lyu, S.; Jiao, W. Perceptions of different stakeholders on reclaimed water reuse: The case of Beijing, China. Sustainability 2015, 7, 9696-9710. [CrossRef]

28. Pilatakis, G.; Manios, T.; Tzortzakis, N. The use of primary and secondary treated municipal wastewater for cucumber irrigation in hydroponic system. Water Pract. Technol. 2013, 8, 433-439. [CrossRef]

29. Manios, T.; Papagrigoriou, I.; Daskalakis, G.; Sabathianakis, I.; Terzakis, S.; Maniadakis, K.; Markakis, G. Evaluation of Primary and Secondary Treated and Disinfected Wastewater Irrigation of Tomato and Cucumber Plants Under Greenhouse Conditions, Regarding Growth and Safety Considerations. Water Environ. Res. 2006, 78, 797-804. [CrossRef]

30. Petousi, I.; Fountoulakis, M.S.; Tzortzakis, N.; Dokianakis, S.; Stentiford, E.I.; Manios, T. Occurrence of micro-pollutants in a soil-radish system irrigated with several types of treated domestic wastewater. Water. Air. Soil Pollut. 2014, 225, 1-8. [CrossRef]

31. Kiziloglu, F.M.; Turan, M.; Sahin, U.; Kuslu, Y.; Dursun, A. Effects of untreated and treated wastewater irrigation on some chemical properties of cauliflower (Brassica olerecea L. var. botrytis) and red cabbage (Brassica olerecea L. var. rubra) grown on calcareous soil in Turkey. Agric. Water Manag. 2008, 95, 716-724.

32. Cirelli, G.L.; Consoli, S.; Licciardello, F.; Aiello, R.; Giuffrida, F.; Leonardi, C. Treated municipal wastewater reuse in vegetable production. Agric. Water Manag. 2012, 104, 163-170. [CrossRef]

33. Aiello, R.; Cirelli, G.L.; Consoli, S. Effects of reclaimed wastewater irrigation on soil and tomato fruits: A case study in Sicily (Italy). Agric. Water Manag. 2007, 93, 65-72. [CrossRef]

34. Lubello, C.; Gori, R.; Nicese, F.P.; Ferrini, F. Municipal-treated wastewater reuse for plant nurseries irrigation. Water Res. 2004, 38, 2939-2947. [CrossRef] [PubMed]

35. Tzortzakis, N.; Gouma, S.; Paterakis, C.; Manios, T. Deployment of municipal solid wastes as a substitute growing medium component in marigold and basil seedlings production. Sci. World J. 2012, 2012. [CrossRef] [PubMed]

36. Stamatakis, A.; Chrysargyris, A. Municipal Solid Waste Compost (MSWC) in pot culture growing media in Greece. In Municipal Solid Waste: Management Strategies, Challenges and Future Directions; Tzortzakis, N., Ed.; Nova Science Publishers: New York, NY, USA, 2017; pp. 387-414.

37. Xylia, P.; Clark, A.; Chrysargyris, A.; Romanazzi, G.; Tzortzakis, N. Quality and safety attributes on shredded carrots by using Origanum majorana and ascorbic acid. Postharvest Biol. Technol. 2019, 155, 120-129. [CrossRef]

38. Tzortzakis, N.G.; Tzanakaki, K.; Economakis, C.D.C.D. Effect of origanum oil and vinegar on the maintenance of postharvest quality of tomato. Food Nutr. Sci. 2011, 02, 974-982. [CrossRef]

39. Dagianta, E.; Goumas, D.; Manios, T.; Tzortzakis, N. The use of treated wastewater and fertigation in greenhouse pepper crop as affecting growth and fruit quality. J. Water Reuse Desalin. 2014, 4, 92-99. [CrossRef]

40. Byamukama, D.; Kansiime, F.; Mach, R.L.; Farnleitner, A.H. Determination of Escherichia coli contamination with chromocult coliform agar showed a high level of discrimination efficiency for differing fecal pollution levels in tropical waters of Kampala, Uganda. Appl. Environ. Microbiol. 2000, 66, 864-868. [CrossRef]

41. Mami, Y.; Peyvast, G. Substitution of municipal solid waste compost for peat in cucumber transplant production. J. Hortic. For. 2010, 2, 154-160.

42. Gautam, S.P.; Bundela, P.S.; Pandey, A.K.; Awasthi, M.K.; Sarsaiya, S. Composting of municipal solid waste of Jabalpur city. Glob. J. Environ. Res. 2010, 4, 43-46.

43. Zhang, M.; Heaney, D.; Henriquez, B.; Solberg, E.; Bittner, E. A four-year study on influence of biosolids/msw cocompost application in less productive soils in alberta: Nutrient dynamics. Compos. Sci. Util. 2006, 14, 68-80. [CrossRef]

44. Kałuza-Haładyn, A.; Jamroz, E.; Bekier, J. Humic substances of differently matured composts produced from municipal solid wastes and biomass of energetic plants. Soil Sci. Annu. 2020, 70, 292-297. [CrossRef]

45. Weber, J.; Karczewska, A.; Drozd, J.; Licznar, M.; Licznar, S.; Jamroz, E.; Kocowicz, A. Agricultural and ecological aspects of a sandy soil as affected by the application of municipal solid waste composts. Soil Biol. Biochem. 2007, 39, 1294-1302. [CrossRef]

46. Montemurro, F.; Maiorana, M.; Convertini, G.; Ferri, D. Alternative sugar beet production using shallow tillage and municipal solid waste fertiliser. Agron. Sustain. Dev. 2007, 27, 129-137. [CrossRef]

47. Asgharipour, M.R.; Armin, M. Growth and elemental accumulation of tomato seedlings grown in composted solid waste soil amended. Am.-Eurasian J. Sustain. Agric. 2010, 4, 94-101. 
48. Stevenson, F.J. Humus Chemistry: Genesis, Composition, Reactions, 2nd ed.; John Wiley \& Sons: New York, NY, USA, 1994.

49. Noguera, P.; Abad, M.; Puchades, R.; Maquieira, A.; Noguera, V. Influence of particle size on physical and chemical properties of coconut corr' ${ }^{\prime}$ dust as a container medium. Commun. Soil Sci. Plant Anal. 2003, 34, 593-605. [CrossRef]

50. Rietz, D.N.; Haynes, R.J. Effects of irrigation-Induced salinity and sodicity on soil microbial activity. Soil Biol. Biochem. 2003, 35, 845-854. [CrossRef]

51. Karak, T.; Sonar, I.; Paul, R.K.; Frankowski, M.; Boruah, R.K.; Dutta, A.K.; Das, D.K. Aluminium dynamics from soil to tea plant (Camellia sinensis L.): Is it enhanced by municipal solid waste compost application? Chemosphere 2015, 119, 917-926. [CrossRef]

52. Lakhdar, A.; Falleh, H.; Ouni, Y.; Oueslati, S.; Debez, A.; Ksouri, R.; Abdelly, C. Municipal solid waste compost application improves productivity, polyphenol content, and antioxidant capacity of Mesembryanthemum edule. J. Hazard. Mater. 2011, 191, 373-379. [CrossRef]

53. Shanmugam, G.S.; Warman, P.R. Soil and plant response to organic amendments to three strawberry cultivars. In Proceedings of the International Humic Substances Society; Martin-Neto, L., Milori, D., DaSilva, W., Eds.; Embrapa: Sao Pedro, Brazil, 2004; pp. 230-232.

54. Fagnano, M.; Adamo, P.; Zampella, M.; Fiorentino, N. Environmental and agronomic impact of fertilization with composted organic fraction from municipal solid waste: A case study in the region of Naples, Italy. Agric. Ecosyst. Environ. 2011, 141, 100-107. [CrossRef]

55. Warman, P.R.; Burnham, J.C.; Eaton, L.J. Effects of repeated applications of municipal solid waste compost and fertilizers to three lowbush blueberry fields. Sci. Hortic. 2009, 122, 393-398. [CrossRef]

56. Shahalam, A.; Abu Zahra, B.M.; Jaradat, A. Wastewater irrigation effect on soil, crop and environment: A pilot scale study at Irbid, Jordan. Water. Air. Soil Pollut. 1998, 106, 425-445. [CrossRef]

57. Najafi, S.; Mousavi, F.; Feizi, M. Effects of using sub surface drip in irrigation of tomato and eggplant with treated municipal wastewater. Iran. J. Soil Water Sci. 2006, 20, 155-164.

58. Mañas, P.; Castro, E.; De Las Heras, J. Irrigation with treated wastewater: Effects on soil, lettuce (Lactuca sativa L.) crop and dynamics of microorganisms. J. Environ. Sci. Health-Part A 2009, 44, 1261-1273. [CrossRef]

59. Papafilippaki, A.; Nikolaidis, N.P. Comparative study of wild and cultivated populations of Cichorium spinosum: The influence of soil and organic matter addition. Sci. Hortic. 2020, 261, 108942. [CrossRef]

60. Papafilippaki, A.; Paranychianakis, N.; Nikolaidis, N.P. Effects of soil type and municipal solid waste compost as soil amendment on Cichorium spinosum (spiny chicory) growth. Sci. Hortic. 2015, 195, 195-205. [CrossRef]

61. Tzortzakis, N.G.; Economakis, C.D. Maintaining Postharvest Quality of the Tomato. J. Food Qual. 2007, 30, 567-580. [CrossRef]

62. Hargreaves, J.C.; Adl, M.S.; Warman, P.R.; Warman, P.R. The Effects of Municipal Solid Waste Compost And Compost Tea on Mineral Element Uptake And Fruit Quality of Strawberries. Compos. Sci. Util. 2009, 17, 85-94. [CrossRef]

63. Al-Lahham, O.; El Assi, N.M.; Fayyad, M. Impact of treated wastewater irrigation on quality attributes and contamination of tomato fruit. Agric. Water Manag. 2003, 61, 51-62. [CrossRef]

64. Scherer, R.; Lemos, M.F.; Lemos, M.F.; Martinelli, G.C.; Martins, J.D.L.; da Silva, A.G. Antioxidant and antibacterial activities and composition of Brazilian spearmint (Mentha spicata L.). Ind. Crops Prod. 2013, 50, 408-413. [CrossRef]

65. Zavadil, J. The effect of municipal wastewater irrigation on the yield and quality of vegetables and crops. Soil Water Res. 2009, 4, 91-103. [CrossRef]

66. Gattullo, C.E.; Mininni, C.; Parente, A.; Montesano, F.F.; Allegretta, I.; Terzano, R. Effects of municipal solid waste- and sewage sludge-compost-based growing media on the yield and heavy metal content of four lettuce cultivars. Environ. Sci. Pollut. Res. 2017, 24, 25406-25415. [CrossRef] [PubMed]

67. Mohammad, M.J.; Mazahreh, N. Changes in soil fertility parameters in response to irrigation of forage crops with secondary treated wastewater. Commun. Soil Sci. Plant Anal. 2003, 34, 1281-1294. [CrossRef]

(C) 2020 by the authors. Licensee MDPI, Basel, Switzerland. This article is an open access article distributed under the terms and conditions of the Creative Commons Attribution (CC BY) license (http://creativecommons.org/licenses/by/4.0/). 